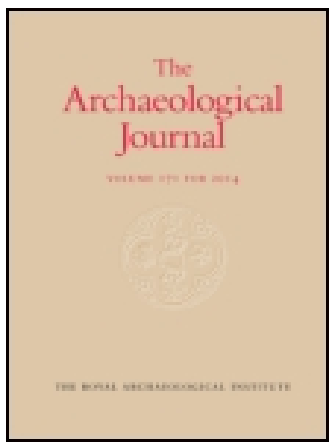

Archaeological Journal

\title{
An Account of Some Painted Glass from a House at Leicester
}

\author{
G. McN. Rushforth M.A. F.S.A.
}

To cite this article: G. McN. Rushforth M.A. F.S.A. (1918) An Account of Some

Painted Glass from a House at Leicester, Archaeological Journal, 75:1, 47-68, DOI:

10.1080/00665983.1918.10853325

To link to this article: http://dx.doi.org/10.1080/00665983.1918.10853325

Published online: 17 Jul 2014.

Submit your article to this journal $\square$

Џ Article views: 2

Q View related articles $\square$ 


\section{AN ACCOUNT OF" SOME PAINTED GLASS FROM A HOUSL AT LEICESTER.}

By G. McN. RUSHFORTH, M.A. F.S.A.

Sometime, probably, in the first quarter of the sixteenth century, a well-to-do citizen of Leicester decorated the long range of lights which formed the window of the hall or principal room of his house in Highcross street with a series of religious subjects in painted glass. There were a Life of Mary, the Seven Sacraments, and the Seven Corporal Works of Mercy, together with some isolated figures of saints, and some local heraldry. There the glass remained for three centuries and more, apparently valued and taken care of, at least in the eighteenth century, when we have evidence that it was releaded. ${ }^{1}$ Moreover it was thought sufficiently interesting to be described by the local historians, Throsby and Nichols. ${ }^{2}$ When the latter wrote, only one subject ('feeding the hungry' from the Works of Mercy) seems to have been missing from the series, which then occupied the twenty-eight lights of the window. About 1860, when the house was sold by the Rev. Richard Stephens, he for the first time removed the glass from its original setting, and carried it away to his vicarage at Belgrave, where, however, it seems never to have been unpacked. On his death in I87I a sale of his effects took place, and Mr. Thomas North, a well-known antiquary of Leicester, bought the glass for the modest sum of $f_{17}$. Perhaps at this sale, if it was not earlier, another subject, the Adoration of the Magi, was separated from its fellows, but not lost; for it fortunately turned up in a London sale-room a few years ago, and was acquired and brought back to Leicester by the late Mr. S. Perkins Pick,

\begin{abstract}
${ }^{1}$ Local glaziers have scratched their names and the date on the scenes of the Assumption (1764) and Burial (1796).
\end{abstract}

${ }^{2} \mathrm{~J}$. Throsby, History of Leicester (Leices- ter, 1791), p. 274; J. Nichols, Bibliotbeca Topograpbica Britannica, vol. viii (1790), History and Antiquities of the County of Leicester, vol. i, part ii (London, 1815). p. 514 and pl. xxxri and xxxrii. 
F.S.A. At the annual meeting of the Leicestershire Architectural and Archaeological Society on the 29th January, I872, it was decided to purchase the glass from Mr. North at the price which he had paid for it. At subsequent meetings of the Society during that and the next two years Mr. North systematically and carefully described and illustrated the glass, and his account was printed in the fourth volume of the Society's Transactions, ${ }^{1}$ together with tinted lithographic reproductions of the panels, made from what must have been very faithful drawings (based no doubt on tracings from the originals) by Mr. J. C. Traylen. ${ }^{2}$ When Mr. North read the last of his papers, he concluded with the expression of a hope that the glass would be properly exhibited. However, nothing further was done; a proposal that it should be presented to St. Martin's church was dropped ${ }^{3}$; and the panels were packed away and almost forgotten till I happened 10 make some enquiries about them, and by the kindness of the Society was allowed to examine, and later to speak about them at the annual meeting on the 29th January, 19I7. The substance of what I said on that occasion will be found in the following pages. I may add that the papers of Mr. North, a very conscientious and well-informed antiquary, are still indispensable for the study of the glass; and those who want information especially about the legendary subjects must refer to them. I have endeavoured not to reproduce any of his material, and have devoted my attention to details and aspects of the case which were not dealt with by him. A new set of illustrations has been provided by the admirable photographs recently taken by Mr. Sydney A. Pitcher of Gloucester. Since the return of peace the glass has been given by the Leicestershire Archaeological Society to the Leicester Museum, where it can now be seen very satisfactorily exhibited in the windows of one of the principal rooms. ${ }^{4}$

Before we examine the glass itself, something may be

\footnotetext{
${ }^{1}$ Transactions, iv $(1878), 138-145,187-$ $190,199-202,220-223,232-242,250-252$, 254-262.

2 I have been unable to ascertain whether these drawings are still in existence.
}

Transactions, iv, 133,134 .

4 The panel belonging to Mr. Pick has been purchased from his executors by the Leicester Museum and Libraries Committee, and is exhibited with the others. 
said about that characteristic which gives it its special interest. Though the subjects are, apart from some heraldic devices, exclusively religious, the series was made for a house and not for a church. People are so accustomed to think of painted glass windows in connexion with churches, that they forget that, at the end of the middle ages, there must have been a considerable amount of painted glass in both town and country houses of the best class in England. In the fifteenth century there was an immense production of painted glass for churches. Records and surviving fragments suggest that at the death of Henry VIII, it was the exception to find a Perpendicular church window which had not been filled with it. It was natural and obvious that this attractive and fairly plentiful, if rather costly, form of decoration should find its way, not only into municipal and semi-public buildings, but also into private houses. Very little of this domestic glass has survived. Glass is fragile, and exposed to accidents. Medieval houses, largely built of timber, were specially liable to destruction by fire, or else they have been rebuilt as architectural fashions changed; and this was peculiarly frequent with the houses of the wealthy and the great, which were just those where painted glass was likely to be found. As a rule, it would find no place in a house rebuilt in the new style. Of that which has survived much the larger part consists either of decorative quarries, or of heraldic designs. Figure subjects are very rare. Such are the sets of roundels of the Months with their characteristic occupations at Norbury hall, Derbyshire, and Colville hall, Essex, very like those in the Mayor's parlour of Leicester Town hall. But these are secular subjects. As a set of religious pictures for the window of a private house the Leicester glass is unique. A solitary roundel at Norbury hall with the Passion scene of the Flagellation suggests that once there may have been a religious series there also. A closer parallel is a roundel of English fifteenth-century glass (distinctly earlier than that at Leicester) belonging to the Hon. H. D. Maclaren, M.P., lately discussed and illustrated in $\mathcal{T}$ be Burlington Magazine. Its subject, giving drink to the thirsty, shows that it belonged to a set of the Works of Mercy (one of the Leicester subjects); and it may have come from some house in Coventry, where it 
can be traced in the eighteenth century. ${ }^{1}$ But for range and completeness the Leicester glass is unequalled, and it forms a monument of a type of domestic glass which has almost entirely vanished. That there was a great deal more of it is suggested by such a statement as that of John Aubrey the antiquary, who says that, when he went up to Trinity college, Oxford, in 1642 , ' crucifixes were common in the glasse windowes in the studies' windowes; and in the chamber windowes were canonized saints (e.g. in my chamber window, St. Gregorie the great, and another, broken) and scutcheons with the pillar, the whip, the dice, and the cock.' ${ }^{2}$ A college is not quite the same thing as a private house; but that religious subjects were to be found in considerable quantity in the windows of private dwellings is proved by the royal injunctions relating to the change of religion, issued on the accession of Edward VI in 1547 , and again in 1559 by Elizabeth, in which the parochial clergy are directed to ' take away, utterly extinct, and destroy (among other objects) pictures, paintings, and all other monuments of feigned miracles, pilgrimages, idolatry, and superstition, so that there remain no memory of the same in walls, glass windows, or elsewhere within their churches and houses; and that they exhort all their parishioners to do the like within their several houses.' ${ }^{3}$ In the case of churches it is obvious that the injunction was very unequally obeyed. But the rarity of religious subjects in house windows suggests that their deliberate removal was much more common, though the other destructive agencies mentioned above may be held responsible for a considerable share in their disappearance. It may be that the owners of the Leicester glass during the critical period were out of sympathy with the tendency of the changes in religion, even if they were not actual recusants, and so the most dangerous period in its existence may have been tided over. The antiquarian interest

I Burlington Magazine, $\mathrm{xxx}$ (1917), p. 214. A roundel of the Annunciation, lent to the Victoria and Albert Museum by Mr. G. Eumorfopoulos, may have come from a church as well as a house. It is described as 'English, about 1450.' Two roundels of fifteenth-century glass with a stag 'lodged' and a monk preaching to geese, "lately preserved in the summerhouse of the par- sonage of Weston-on-Trent' (Derby), and exhibited to the Leicestershire Society in I87 (Transactions, iv, p. 107), probably belonged to a domestic window.

' J. Aubrey, Brief Lives, ed. A. Clark (Oxford, 1898), ii, 322.

${ }^{3} \mathrm{H}$. Gee and W. J. Hardy, Documents illustrative of Englisb Cburcb History (London, 1896), p. 428 . 
which tended to preserve such things began in the seventeenth century, even before the civil war, and it was well established in the eighteenth, when we know that the glass was releaded on two occasions. Nevertheless, there must have been an unusual chain of fortunate circumstances which conspired to preserve so fragile a set of pictures from the many influences and accidents which would be inimical to so prolonged a life as it has had.

Turning now to the classification of the subjects, this is partly determined by the form of the pieces of glass on which they are painted. Of the twenty-eight in existence (including the fragment of 'feeding the hungry'), twentythree are roundels, and five are more or less rectangular oblongs. The latter with their single figures evidently form a class by themselves : Christ ${ }^{1}$ between two male and two female saints. The roundels, with the exception of two which are heraldic, present scenes with several figures, and are divided among three series. Two of these are clearly the Seven Sacraments and the Corporal Works of Mercy. Only six of the latter are in existence, but we shall see that there is good reason for thinking that there must have been a seventh, which has been lost. The remaining eight, which Mr. North classified partly as 'Incidents in the life of Our Lord,' and partly as 'The Life of Mary,'? really belong to one series, which seems to be made up from two sets, a 'Life of Mary' and a 'Joys of Mary,' both very popular subjects in later medieval art. Most of the scenes are common to both sets, but the Birth of Mary is not one of the regular ' Joys,' and the Resurrection is not an incident in her life. Nor is it usual to find both the Assumption and Coronation in the same series. ${ }^{3}$ The inference seems to be that the Leicester series is composite; and this may be due to the number of places to be filled, viz. eight, for the 'Joys' are usually either five or seven in number.

The two heraldic roundels with the town arms and crest show, by the decorative framework in which they are set, that they also occupied a light apiece. We should thus get twenty-nine subjects for the window in its original and

${ }^{1}$ Mr. North reckoned this among the rounds (Trans. iv, p. I40), but the straight sides of the glory of rays show that the piece of glass was of the oblong form.

${ }_{2}^{2}$ Trans. iv, pp. 142 and 200.
${ }^{3}$ Both occur in the paintings (fourteenth century) on the east wall of Chalgrove Church (Oxon.). See Arcbaeologia, xxxviii (1860), pl. xxiv. 
perfect condition. But the window to-day has only twentyeight lights. Either, then, we must reject the missing Work of Mercy, and suppose that there were only six represented; or we must believe that the window has lost one light, which is quite possible at the end where the eighteenthcentury rooms towards the street have been built on to the medieval part of the house. ${ }^{1}$

The roundels are $6 \frac{1}{2}$ inches in diameter, while the oblong pieces measure 9 by 4 inches. The former are framed in designs formed by a lozenge combined with a quatrefoil, terminating above and below in pomegranate finials. The oblongs have frames of similar character, modified to fit their shape. The rest of each light is filled with quarries painted with various devices, among which are several examples of a monogram made out of the letters $\mathrm{R}$ and $\mathrm{W}$; and it is finished with a border of a familiar fifteenth-century type. Both roundels and oblongs are formed of a single piece of glass each. Hence no colour is used except yellow stain, in which, with black or brown pigment, the pictures are carried out. It was only at a later date that the discovery of enamelling on glass made it possible to use other colours in such little scenes. Regarded merely as works of art, these Leicester pictures are not remarkable. They may naturally be supposed to be the product of some local workshop or atelier, from which the glass in the Mayor's parlour will also have come. ${ }^{2}$

It is interesting to consider the place which roundels of this kind hold in the history of painted glass. They must not be confused with the medallion subjects which were a feature of thirteenth-century glass (e.g. in Canterbury Cathedral), for these are made up of pieces of coloured glass leaded together in the ordinary way. The essential fact about the Leicester and similar roundels is that each scene is painted in black, white and stain on a single piece of glass. In the fifteenth century we find such roundels beginning to appear in church windows, set in quarries, generally either in the tracery lights or in subordinate places at the foot of the main lights. ${ }^{3}$ The subjects

\footnotetext{
1 Plans and elevations of the house were published in the Forty-fourtb Annual Report of the Leicester Society of Arcbitects (1917), figs. 4 and 5 , and P. 23 , where the house is dated I $500-155^{\circ}$.

${ }^{2}$ Though the drawing of the Months in
}

the windows of the Mayor's parlour is not by the same hand, the design of the ornamental framework is identical.

${ }^{3}$ N. H. J. Westlake, History of Design in Painted Glass, iii, 147 and plates cv, cvi. 
are simple, e.g. sacred monograms, the emblems of the Evangelists, and various religious symbols. Together with the decorated quarry, they naturally passed into house windows, for which they were specially suited because the treatment interfered but little with the transmission of light, the most important consideration for the interior of a room. At first the subjects would be those that occurred in churches. Thus in the quarry window of the King's Head, Aylesbury, which the shields of Henry VI and his queen date about $145^{\circ}$, there was a set of roundels of the Evangelistic emblems, though only that with the lion of St. Mark survives. Then secular subjects would come in, such as the Months; e.g. those in the Mayor's parlour at Leicester, and those at Norbury hall. Probably the series depicting the culture of the vine, which once existed in an old house (Chilwell) near Nottingham, ${ }^{1}$ was in the form of roundels. But the development of the roundel in English house windows may have been partly due to another influence, perhaps of not less importance, coming from the continent. All students of painted glass are familiar with those characteristic miniature pictures or designs on a single piece of glass, sometimes rectangular, sometimes circular, often of Swiss origin, and executed for house windows. There are a great many about in England in museums or private collections, and some have even found their way by gift into churches. They are still very numerous, but at one time there must have been thousands of them. Their great period of development was in the sixteenth and seventeenth centuries. But this characteristic form of house decoration did not originate in Switzerland. The earliest evidence for its existence is to be found in western Germany and Flanders. It was in the prosperous and art-loving cities of Flanders that the amenities of domestic life and the refinements of house decoration were developed in the circles of wealthy citizens and merchants, at a time when in other countries art was still monopolised by the Church, or when its secular use was almost exclusively confined to the habitations of kings and nobles. One refinement, developed in the course of the fifteenth century in the Low Countries, was the

\footnotetext{
1 Barnaby Googe, Four Bookes of Husbandry (1578), mentioned by Dr. Nelson, Ancient
} Painted Glass in England, p. 35. 
decoration of the house window, not only with coats of arms, but with pictures in grisaille and yellow stain on single pieces of glass, either round or oblong. It has been suggested that the style was derived from the grisaille miniatures in illuminated manuscripts produced in the latter half of the fifteenth century, mainly at Bruges and Ghent, for the dukes of Burgundy, the sovereigns of the country. ${ }^{1}$ These early specimens have rarely survived, but we may see them sometimes represented in contemporary pictures by Flemish painters, which show interiors of rooms with their windows (especially the upper lights) decorated in this way. There is a good example in Memling's diptych (dated 1487) of Martin van Nieuwenhove and the Madonna, in the hospital of St. John at Bruges. In the window behind Martin's head is an oblong panel with a picture of his patron, St. Martin, evidently leaded in the ordinary way. But behind the Virgin we see, not only an heraldic leaded window including emblematic roundels, just like the later Swiss ones, but the upper lights of the other window have subject roundels set in quarries, the one visible being St. George and the Dragon. This fashion among the wealthy Flemish burghers may well have suggested to their counterparts in England, the substantial citizens of towns like Leicester, the idea of beautifying the principal rooms of their houses with sets of little pictures in glass. We know that there was plenty of commercial intercourse between the Flemish cities and England, and both artists and works of art found their way into this country. But though it would have been easy to import sets of small glass pictures of the Leicester type, there is no reason for thinking that the owner of the house in Highcross street, or the glass-painter he employed, derived anything more from a foreign source than the general idea of such window decoration, and to some extent the designs. We have seen how large was the output of English painted glass in the fifteenth century. We shall notice in these pictures a number of details which occur in undoubtedly English representations, and may be regarded as characteristically English. Moreover, the artistic style confirms the impression of an English origin. For these reasons

${ }^{1}$ Hermann Schmitz, Die Glasgemalde der $k$. Kunstgewerbe-museums in Berlin (Berlin, 1913), pp. 64,65 . 

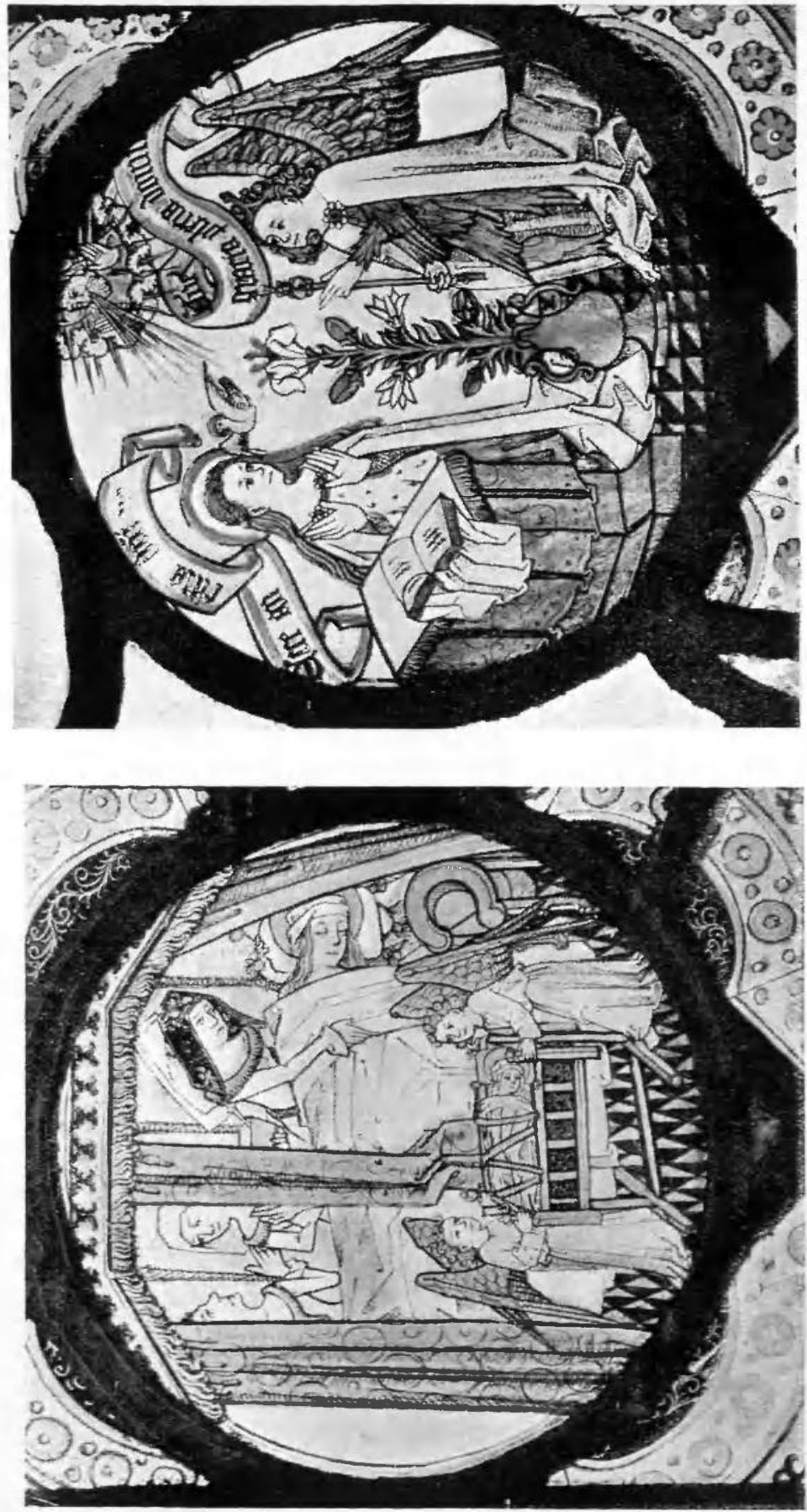
we may believe that the glass was painted in England, and probably in Leicester itself.

The designs of the scenes taken from sacred history or legend are, as usual with English fifteenth-century representations, derived from that common stock of artistic material belonging to what may be called northern or mid-continental (as distinguished from Italian) art, which had its chief centres in the region between the Rhine, the Channel, and the North sea. ${ }^{1}$ On the other hand, the more simple and homely scenes of the Works of Mercy and, to some extent, those of the Sacraments are less dependent on an artistic tradition, and may be attributed more or less to the invention of English artists.

In describing the glass we may begin with the Life or Joys of Mary.

(1) The Birth of Mary (plate I, I). This subject may be readily distinguished from the Nativity of Jesus by the scene being laid in the bedroom of a house. In northern art the chief feature is always the big bed, such as we see here. But the incidents vary. Sometimes the swaddled infant is being handed by the nurse to Anne sitting up in the bed; sometimes it is being washed in front of the bed. The Leicester motive of angels rocking the child in its cradle is unusual. ${ }^{2}$ By the bed stands a characteristic piece of English medieval bedroom furniture, the close stool, which we shall meet with again. ${ }^{3}$ The attendant in the background bringing a basin with a spoon in it has a common kerchief on her head, but the lady who is arranging the bed-clothes wears an elaborate head-dress of a type which forms the transition from the so-called butterfly or wired head-dress (characteristic of the time of Edward IV) to the pedimental fashion which came in with the sixteenth century. ${ }^{4}$ The face is framed by a black frontlet embroidered in gold following the curve of the head, and the wired veil is reduced in size. In the later fashion the frontlet forms a peak or gable above the forehead,

\footnotetext{
${ }^{1}$ Sce E. Male, L'Art religieux de la fin du Moyen Age en France (Paris, 1908), p. 71, note $I$, etc.

${ }^{2} \mathrm{Mr}$. North called attention to the English type of cradle, comparing (loc. cit. p. 202) Shaw's Ancient Furniture, pl. xli.
}

${ }^{3}$ Compare e.g. Tbe Pageant of Ricbard Beaucbamp (mentioned below), pl. li.

${ }^{4}$ Cf. Druitt, Costume on Brasses, pp. 272, 275 . 
and the veil disappears, the caul becoming a sort of cap or bonnet.

(2) The Annunciation (plate I, 2). This is a typical example of the scene as represented in northern art of the fifteenth century, ${ }^{1}$ except for the fact that the composition is reversed, Mary usually being on the right and the angel on the left. Owing to this reversal the action of Gabriel's hands is contrary, and so far unnatural, for he should have his right hand raised with the traditional gesture of utterance (often described, from one of its uses, as ' benediction '), while his left should hold his virge. The latter object is generally described as a sceptre, which would not be appropriate to an archangel, though in representations of the Hierarchies it naturally appears with those orders (e.g. the Dominations) which have royal attributes. In the older Christian art, Gabriel, as the herald or envoy of the deity, carries a long slender wand, which in western medieval art becomes a virge, and is assimilated in form to a sceptre. ${ }^{2}$ The late Sir W. H. St. John Hope, describing the Annunciation above the altar of Henry V's chantry chapel in Westminster abbey, calls it a mace. ${ }^{3}$

Somewhat unusual is the representation of Gabriel's body and limbs as covered with feathers, together with, apparently, some minor wings in addition to the principal pair at his shoulders. In distinguishing the different orders of angels, the feathered body and multiplied wings belonged originally to the two highest classes, the Seraphim and Cherubim. But by the latter half of the fifteenth century these features appear in English art, not only with an archangel like Gabriel, but even with ordinary angels playing on instruments of music, so often seen in attendance on sacred scenes or personages. Mary wears under her mantle an ermine 'sideless cote-hardie' (in the Assumption scene it has, as often, a set of ornamental gold buttons down the front), a characteristic item in the full-dress of great ladies of the fifteenth century, regularly used in pictures of the

'A 'locus classicus' for the composition is the Annunciation on the outer face of the wings of Hubert and Jan Van Eyck's great triptych at Ghent (c. 1425).

2 For the old tradition as represented in Byzantine art see Didron-Stokes, Cbristian Iconograpby, ii, 299. Fig. $15^{6}$ (p. 95) seems to illustrate the transition to the sceptre form, for the angel announcing the Resurrection holds a long wand tipped with a fleur-de-lys.

3 Archaeologia, lxv (I914), I69. For the development of the mace from the virge see Ll. Jewitt \& Hope, Corporation Plate. 

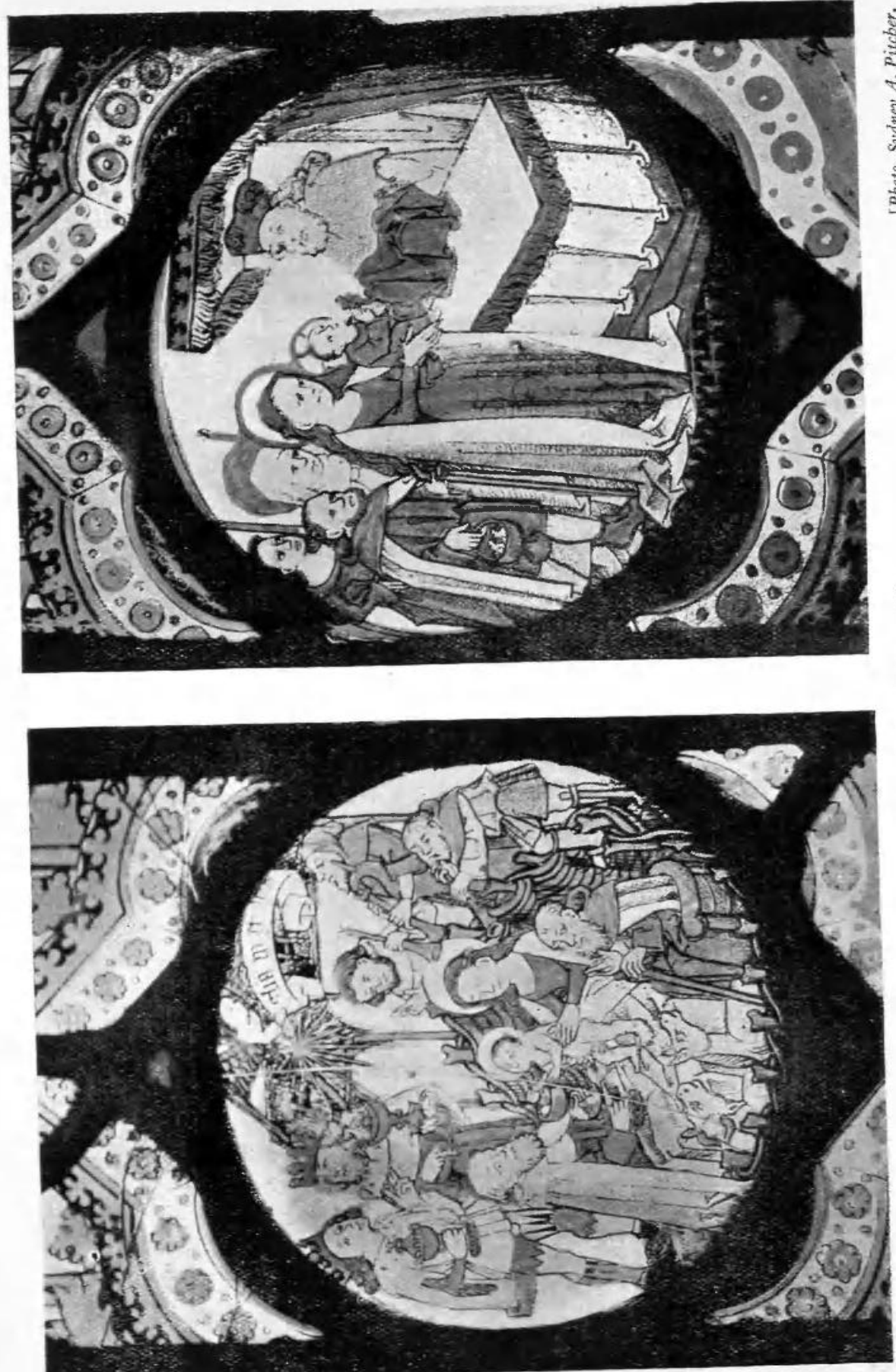

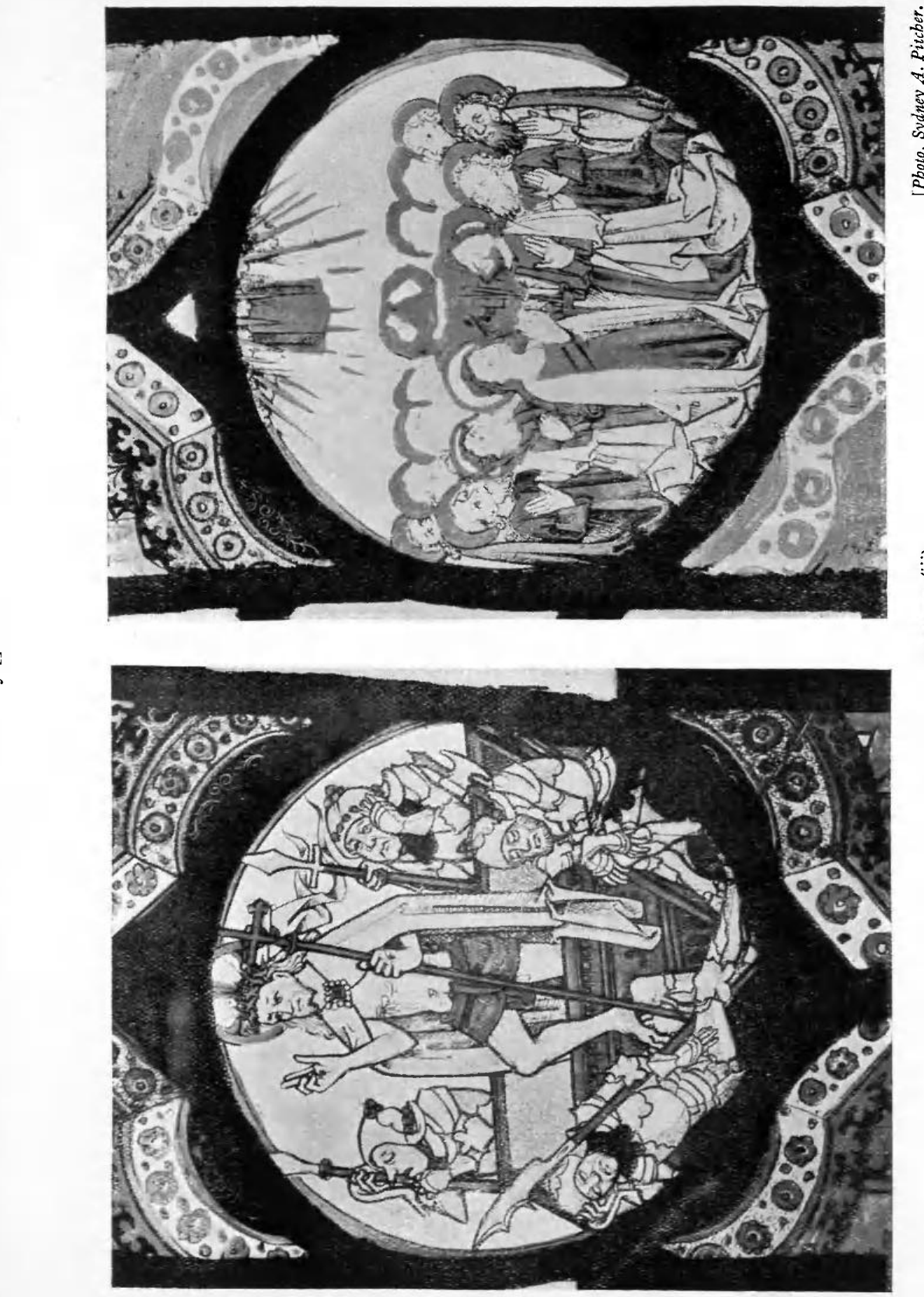
Virgin and other saints (e.g. Katharine) represented as princesses. 1

(3) The Nativity of Fesus (plate II, 3) represented by the offering of the Three Kings together with the visit of the Shepherds, an unusual combination. ${ }^{2}$ Otherwise it contains the characteristic elements of the scene (or rather, scenes) as represented in northern art. Such are the open stable with its uprights and broken thatched roof through which the star shines, and the screen formed by a wattle-fence. ${ }^{3}$ It will be noticed that Mary (as often) is lying or sitting up in a bed, and that Joseph is seated in the familiar close stool as if he were in the bedroom of a house. The position of the ox and ass in front of the group is unusual. The grouping of the kings follows the regular arrangement, and the foremost of them is offering gold in the form of coins which, in spite of the difference of metal, a popular legend identified with the thirty pieces of silver. ${ }^{4}$ On the other hand it is not very common to see the shepherds playing on their pipes. ${ }^{5}$

(4) The Presentation or Purification (plate II, 4) is a typical example of a composition which is common in northern art of the period. The priest (often confused with Simeon) stands behind the altar under its canopy, and receives the child from Mary in his covered hands. Hewears a mitre like a bishop (and is sometimes so described), but as usual it has an archaic form, though occasionally it is represented in the late medieval shape. Otherwise he seems to be vested like the bishop in the Confirmation scene described below (p. 6o). Another stereotyped detail is the form of the basket with the doves held by Joseph.

(5) The Resurrection (plate III, 5) follows the regular design, repeated, with more or less minor variation, in hundreds of examples. Jesus (often wearing the crown of thorns), holding the cross staff with pennon attached, steps out of a table tomb with panelled sides, generally set diagonally. At the angles are four soldiers, three being

\footnotetext{
${ }^{1}$ Druitt, Pp. 244, 275.

${ }^{2}$ It evidently occurred in a muchdamaged fifteenth-century wall-painting in Friskney Church (Lincs.). Arcbaeologia, lix (1905), pl. lxxxv.

' For these details see Male, op. cit. p. 25.

- See Mr. G. F. Hill's article in Arcbaeo-
}

logia, lix (1905), 235-244, reprinted in $\tau$ be Medallic Portraits of Cbrist (Oxford, 1920). 5 This is found in the east window of St. Peter Mancroft, Norwich, with other details which appear at Leicester (plates ix$x i$ in the Rev. F. J. Meyrick's account of the glass [Norwich, I9II]). See also Male, op. cit. p. 37 . 
asleep. Their armour is characteristic of the latter half of the fifteenth century. ${ }^{1}$ Each has a different weapon, viz. a spear, a pike with cross blade, a glaive (left), and a pole-axe (right).

(6) The Ascension (plate in, 6) reproduces a design which became the regular type for the scene in the art of the countries north of the Alps, and is very common. Mary and the Apostles kneel round the foot of a mound marked with the footprints of Christ, the skirts of whose garments are disappearing in clouds of glory above. ${ }^{2}$

(7) The Assumption (plate Iv, 7) is only a fragment, but enough remains to show that, when perfect, it.was a roundel and not an oblong. It is unnecessary to dwell on the design, which is of the regular type. But we may note that the crescent moon on which Mary stands (derived from Revelation, xii, I) begins to appear about the middle of the fifteenth century, and by its end had become common. ${ }^{3}$

(8) The Coronation of Mary (plate Iv, 8). Putting aside the earlier and simpler form in which Christ and Mary are seated side by side, there are two main versions of this subject in late fifteenth-century northern art. In the one, the Father and Son enthroned, with the Dove between them, crown Mary seated or kneeling in front. In the other, all three Persons of the Trinity are represented in human form, as here. In both, the tiara or triple crown is worn, and sometimes, as here, it is given to Mary as well. A variety was the use of the imperial arched crown, but in English art the papal tiara is far more frequent. ${ }^{4}$ In any case the idea was to invest God with the attributes of the highest earthly dignity. It may be noticed that in The Pageant of Richard Beauchamp, Earl of $W$ arwick, the emperor and empress wear triple crowns

1 The armour (especially the helmets) of the soldiers in a window (c. 1480) of Ashtonunder-Lyne church (Lancs.) is of very similar pattern. See $A . \mathcal{F}$. lxx, I-10, for a full description of the window by Dr. Philip Nelson, in which (pp. 2, 7) the character of the armour is noted.

2 See Male, op. cit. p. 53.

${ }^{3}$ Ibid. p. 220. It occurs in the chantry chapel of Henry $\mathrm{V}$ in Westminster abbey (c. 1440-50). Arcbaeologia, lxy (1914), p. $16 \mathrm{~g}$.
According to E. Male, op. cit. p. 55, the same is true of French fifteenth-century art. The only examples of the imperial crown in English glass that I can recall are at Doddiscombsleigh (Devon), and in the east window of Holy Trinity, Goodramgate, York; in both cases it is worn by all three Persons of the Trinity. For an example of a Trinity with ordinary crowns see Catalogue of Exbibition of Englisb Medieval Alabaster Work (Oxford, I9I3), pl. v $d$. 


$$
\frac{Q}{17}
$$




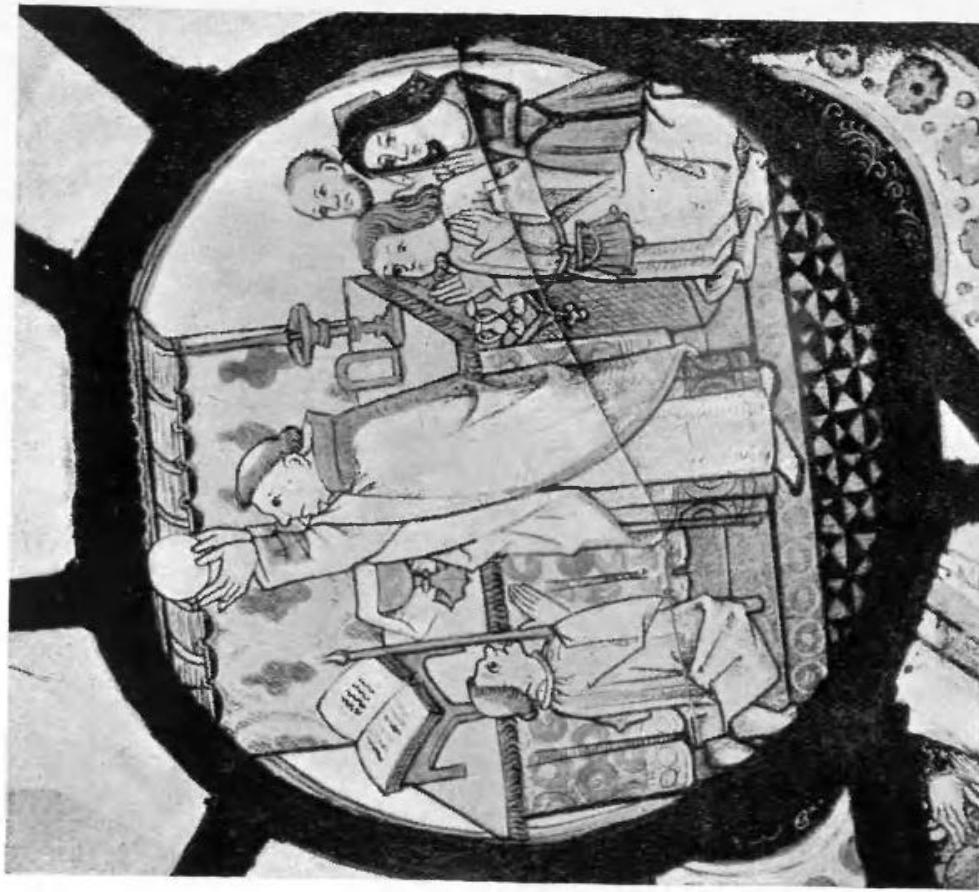

हैँ

$\dot{\Xi}$

范

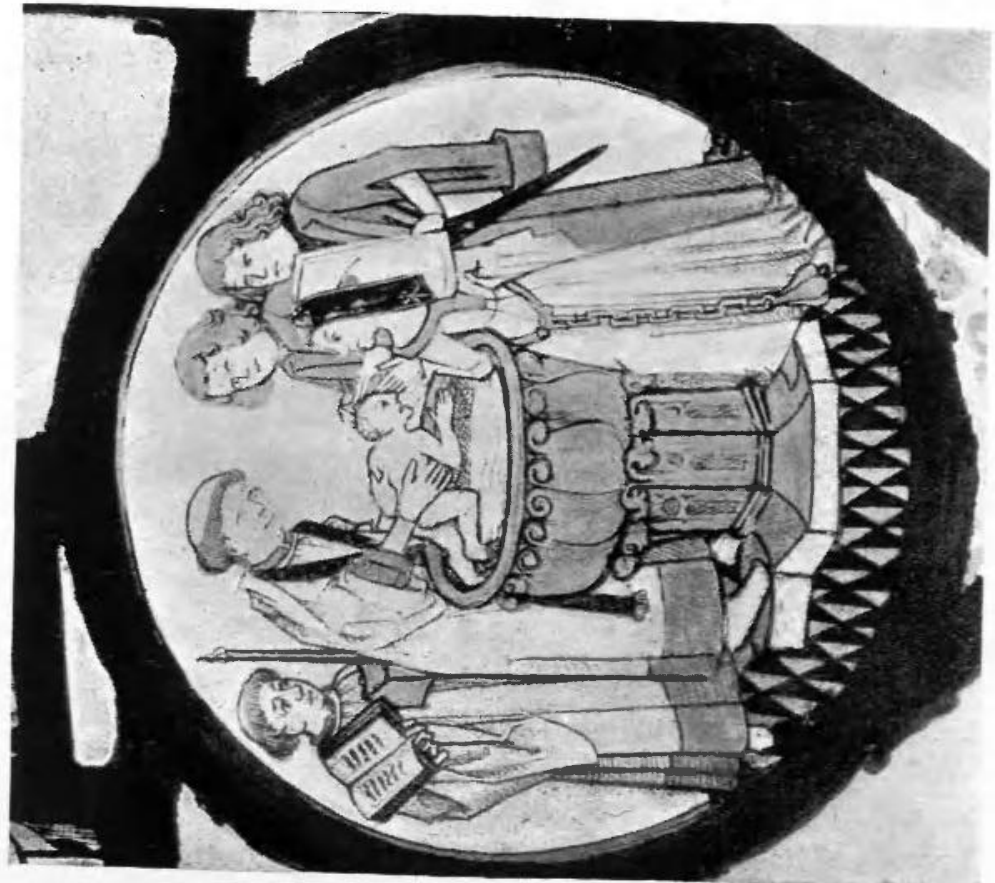

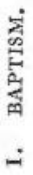


exactly like that of the pope. ${ }^{1}$ Hence it is possible that in this late fifteenth-century northern art the triple crown was regarded as the symbol of the highest earthly dignity, whether imperial or papal. Another detail in these representations, to which attention may be called, is the form of triple crown worn by the Son, having only two foliated crowns of the ordinary type. His third crown is the crown of thorns. ${ }^{2}$ Fragments of a late fifteenth-century window at Great Malvern show this feature in a Trinity, and it also occurs in English alabaster tables. ${ }^{3}$

THE SEVEN SACRAMENTS.

The Seven Sacraments were a frequent subject for church windows in the fifteenth century, ${ }^{4}$ but there is no other example of its use in English domestic glass.

( $\mathrm{I}$ ) Baptism (plate $\mathrm{v}, \mathrm{I}$ ). The priest, in surplice (the sleeves turned well back) and crossed stole, is about to immerse the child in the font. Behind him, the surpliced clerk holds a chrismatory and lighted taper in one hand, and the open service book in the other. The costume of the godparents belongs to the end of the fifteenth century. Attached to the lady's girdle by a chain is a pomander, which in real life, we may suppose, was not of quite so ponderous a character.

The form of the font is remarkable, and unlike English fifteenth-century types. Its main features-the circular form, the globular shape of the bowl, and the band of carved foliage round it-are curiously reminiscent of a group of thirteenth-century Leicestershire fonts. One example, notable for its bands of carved foliage, is in All Saints' church, Leicester, but it is supported on detached shafts. The font at Burrough-on-the-hill, with its globular bowl resting on a solid stem, is in form still more like the one

1 Plates xxxiv, xxxv ; cp. xiii. In the window already referred to $\left(c .14^{80}\right)$ at Ashton-under-Lyne (Lancs.) pope and emperor appear in the same scene wearing triple crowns of rather different patterns.

2 So in the east window of Holy Trinity,
Goodramgate, York, the Son's imperial crown rises out of the crown of thorns.

${ }^{3}$ Proceedings Soc. Ant., 2nd ser., xxxi (1918), fig. 4 facing p. 59, where the 'torse' (as in fig. 3 ) is obviously the crown of thorns. Notable examples are those at Doddiscombsleigh (Devon) and Buckland (Glos.). 
in our picture. ${ }^{1}$ It is not impossible that this type of font may have supplied the local artist with a model which he has, of course, translated into the conventional decorative forms of the fifteenth century.

(2) Mass (plate v, 2). Mr. North called attention to most of the ordinary features of the scene, but we may note that the server holding a torch appears regularly in medieval pictures of mass, the moment of the elevation being usually chosen. Sometimes it is the only light; and here, it will be observed, there is only one candlestick on the altar. Beside it is the Pax. Instead of being placed upon the commoner cushion, the missal is set on a desk with feet. ${ }^{2}$ A curious feature is the credence in the form of a bracket, attached to the right or south end of the altar. No exact parallel seems to be known, but it is evidently a variety of the recess or niche for the cruets, hollowed out of the end of the altar, which is seen in a number of (mostly fifteenth-century) representations, and has been found in existing altars. ${ }^{3}$

(3) Confirmation (plate vi, 3). The children, as usual in such scenes, are all so young as to be still in arms. The medieval rite, as here represented, consisted in the bishop anointing the child's forehead with the chrism in the form of a cross. The chrismatory, as usual, is held by a chaplain in surplice and amess. The bishop has his mitre and staff (held by the vexillum tied to it) but otherwise wears his ordinary or quire habit, viz. tippet with hood, chimere, and rochet ; but it is not easy to distinguish this from the academical costume of doctors. ${ }^{4}$

(4) Penance (plate vI, 4). The priest is in a surplice with crossed stole, but it is not clear what covers his head, whether amice or amess. The big carved chair in which

\footnotetext{
I Cox \& Harvey, Englisb Cburcb Furniture, pl. facing p. 206. The font in All Saints', Leicester, is figured in Glimpses of Ancient Leicester by Mrs. T. Fielding Johnson (and ed., Leicester, I906), p. 137. See also F. Bond, Fonts and Font-Covers (1908), p. 221 .
}

${ }^{2}$ For other English examples see Alcuin Club Collections, i, pl. viii, 5 ; $\mathrm{x}$, pl. vii.

${ }^{3}$ See the late Sir W. H. St. John Hope's Englisb Altars (Alcuin Club Coll. i), pl. viii, I. There is a good example on an alabaster table of the martyrdom of St. Thomas of Canterbury in the British Museum (Guide to tbe Mediaeval Room (1907), fig. 50). The recess exists in altars at Much Wenlock priory (Salop) and Castleacre priory (Norfolk), as I learned from Sir W. Hope.

'See the Rev. F. E. Brightman's note in R. T. Günther's Brasses in Magdalen College Cbapel, Oxford (Oxford, 1914), p. v; and cp. Druitt, Costume on Brasses, p. 123 ff. In the corresponding scene at Doddiscombsleigh, the bishop wears mitre, red gown and tippet edged with white fur, and stole. 


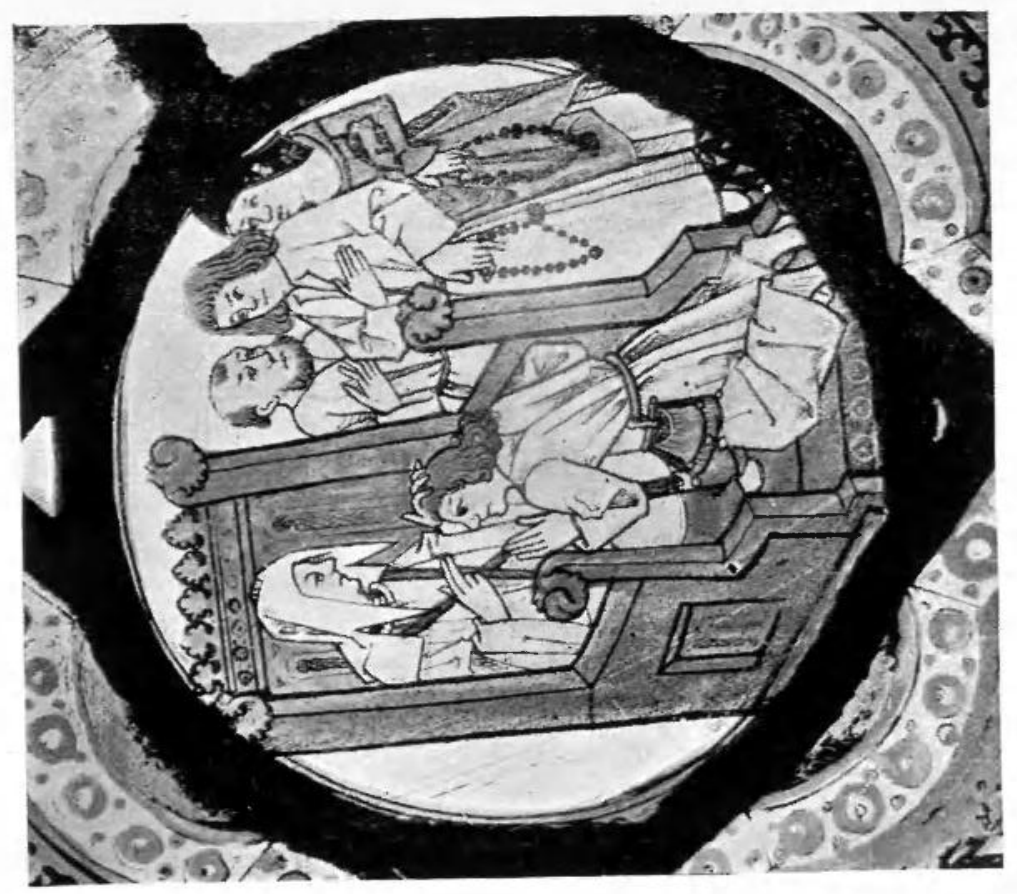

हैं
हैं
ते
के
है
ह

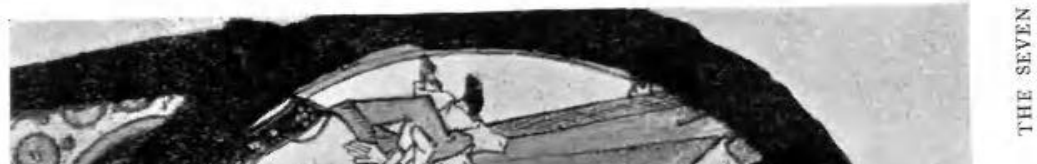

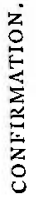

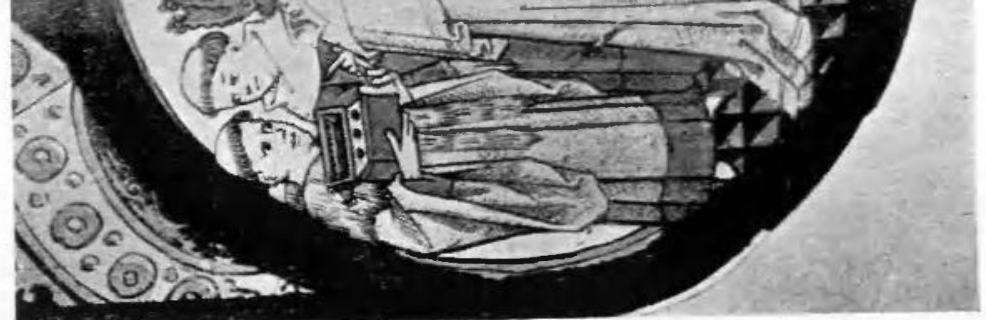



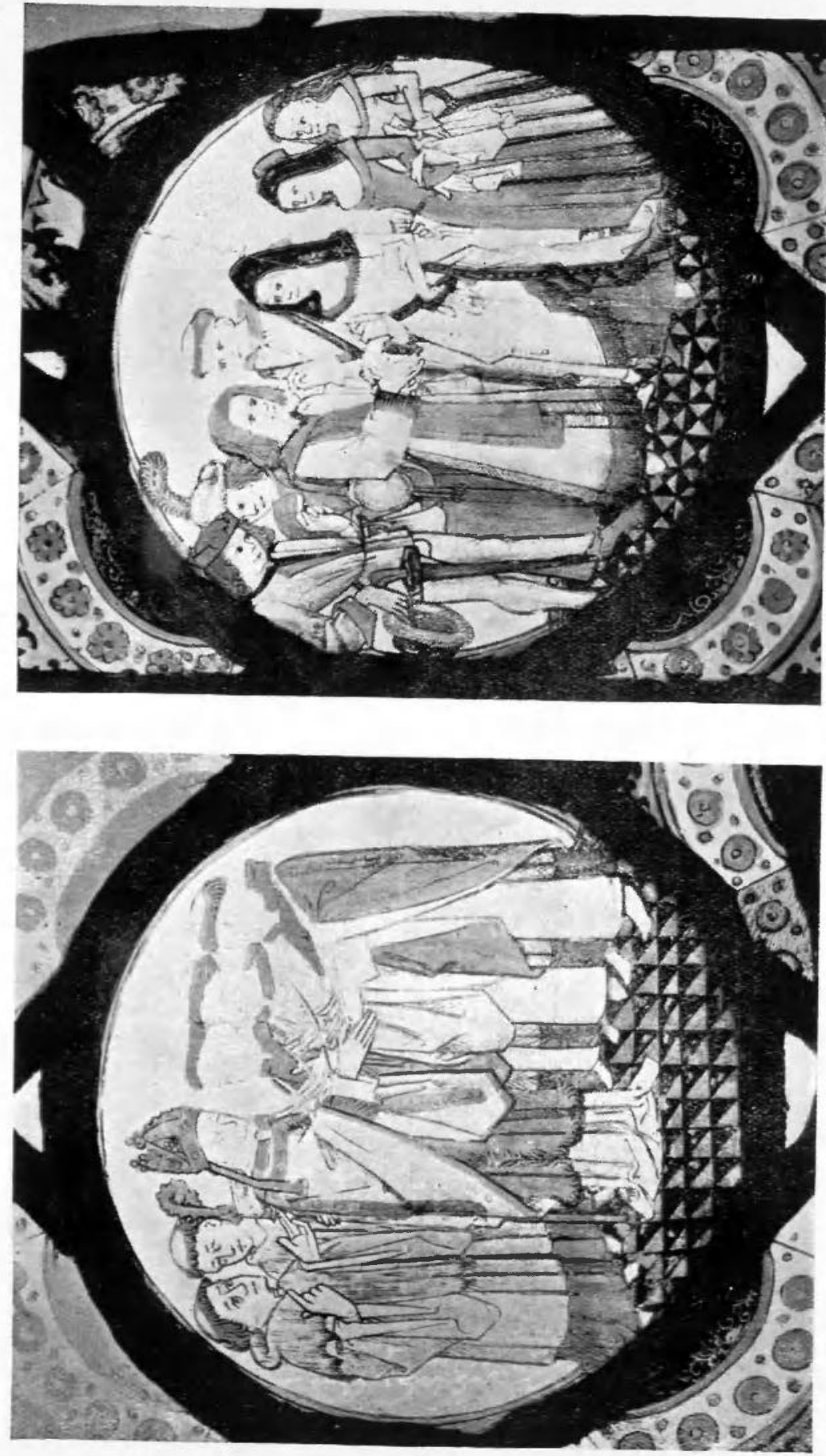

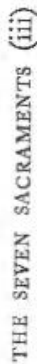


he sits represents something with which the artist was familiar, and one wonders whether some of the medieval chairs still existing in various churches may not have been used for this purpose. ${ }^{1}$

(5) Orders (plate viI, 5). The outlines have become faint in that part of the picture which includes the action of the bishop and the ordinands; and Mr. North did not realise that the moment represented is, not that of anointing the priests' hands, but the tying together of the hands which had previously been anointed. The white bands or ribands used for this purpose pass round the neck so as to support the hands, for they remained tied till the end of the service. It is curious that this motive should be chosen, and not the more crucial moment of the anointing, or of the traditio instrumentorum, when the bishop delivers the chalice and paten. ${ }^{2}$ To this day in the Roman rite the hands are tied with a white riband, as here; and in a Roman Pontifical printed at Venice in 1520 are pictures showing it passing round the neck (as here) in order to support the hands till the end of the ceremony. At the traditio the ordinands only touch the vessels with their fingers. ${ }^{3}$

(6) Matrimony (plate vir, 6). Mr. North suggested that, as the bride is not represented as a maiden, with her hair loose and the nuptial veil, she is being married a second time. This idea is improbable and unnecessary. She wears simply the fashionable head-dress of the day, which was described above. ${ }^{4}$ All the ladies carry handkerchiefs, and one of them has a pair of gloves also. The bridegroom wears a characteristic civilian dress of the end of the fifteenth century, ${ }^{5}$ and the 'best man' behind him (who holds his hat for him) one of a more youthful type.

I Such chairs are described in F. Bond's
Stalls and Tabernacle Work in Englisb
Cburcbes (Oxford, 1910), p. I 55, sqq.;
Cox \& Harvey, Englisb Cburcb Furniture,
p. 253 .
2 In the glass at Doddiscombsleigh the
anointing seems to be represented, a chaplain
attending with the chrismatory. The
chrismatory does not appear at Leicester,
for it has been finished with.
3 The illustrations from the Venice
Pontifical of 1520 are reproduced in
Pontifical Services by F. C. Eeles, iii (Alcuin

Club Collections, viii, 1907), pp. 26, 27. I owe this reference, and also the details about the modern Roman rite, to the late Rev. H. M. Bannister.

${ }^{4}$ So in the glass at Doddiscombsleigh and Buckland.

5 An almost exact parallel may be seen in the brass of Geoffrey Kidwelly (d. 1483) at Little Wittenham (Berks.), figured by Druitt, pl. facing p. 120; and see ibid. p. 209 for a description of the hood with cap attached hanging over the right shoulder, which appears in our picture. 
(7) Extreme Unction (plate viri, 7). The scene follows the usual type, and calls for no special notice. It will be observed that the bed is raised above the paved floor on a wooden platform, a common feature in pictures of medieval bedrooms of the better class. ${ }^{1}$ In the humbler type, which appears in 'Visiting the sick' (p. 63 below), the bed stands on the floor.

THE CORPORAL WORKS OF MERCY.

The scenes of this series do not provide much variety, and require litcle comment. But it will be noticed that, in most of them, the costume of the chief figure, viz. the benefactor, suggests a rather later date than that of the scenes previously described. In particular, his broadtoed shoes are characteristic of the sixteenth century; and the general effect may be described as 'Tudor.'

Like Mr. North, we may take the scenes in the order suggested by Matthew, xxv, 35, 36, where, however, there are only six works. To make up the sacred number of seven, Burial of the Dead was added on the strength of a passage in the Book of Tobit (i, I 7 ).

(I) Feeding the l ungry. Only a fragment of this survives, now leaded into the ornamental frame of the Mass roundel (plate $\mathbf{v}, 2)$. It shows part of a large wicker basket full of loaves, and a hand about to take one of them. Evidently the benefactor was standing by the basket and distributing the loaves to poor people about him, just as in the corresponding scene of the well-known window of the Works of Mercy in All Saints' church, North Street, York. ${ }^{2}$

(2) Giving drink to the thirsty (plate vin, I). The jug and wooden cans or tankards ${ }^{3}$ suggest that the drink is something stronger than water. Just the same elements are found in the scene in the York church.

(3) Sbeltering the stranger (plate Ix, 2).

(4) Clotbing the naked (plate Ix, 3).

\footnotetext{
${ }^{1}$ E.g. Obituary Roll of Fobn Islip (Vetusta Mon. viii, part iv), pl. xxi.

${ }^{2}$ P. J. Shaw, An Old Tork Cburcb (1908).
} 


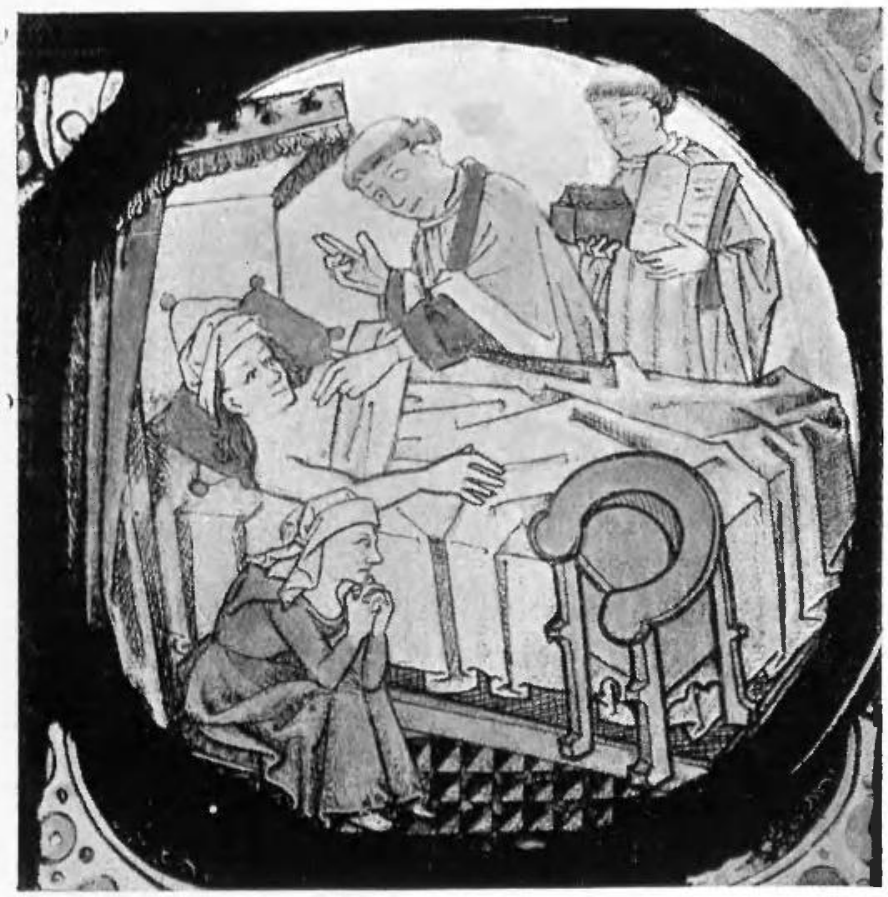

THE SEVEN SACRAMENTS (iv)

7. EXTREME UNCTION. 


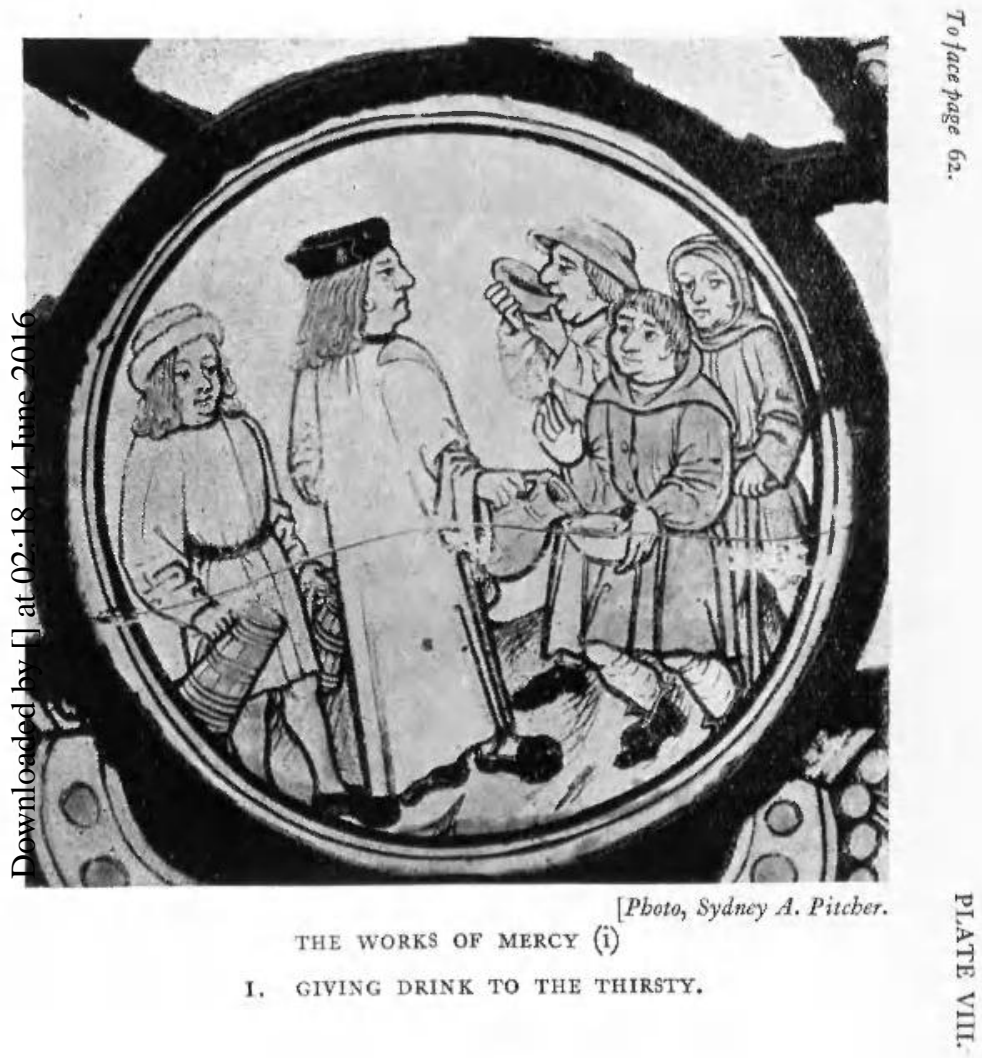




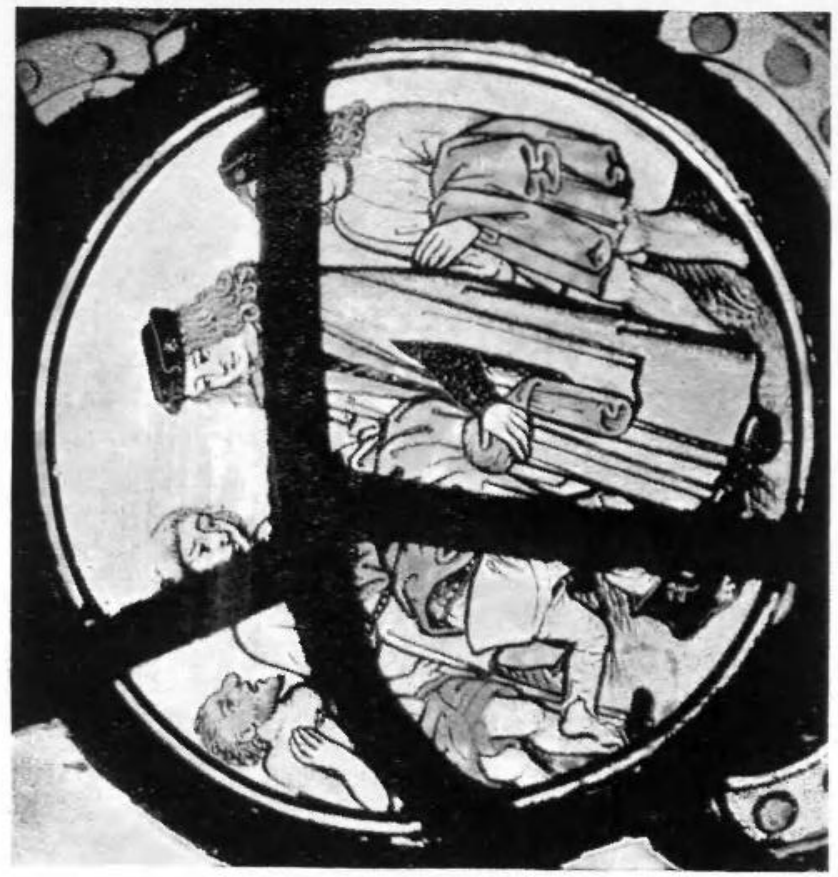

$\Xi$<smiles>[CH]1[CH]CC1</smiles>

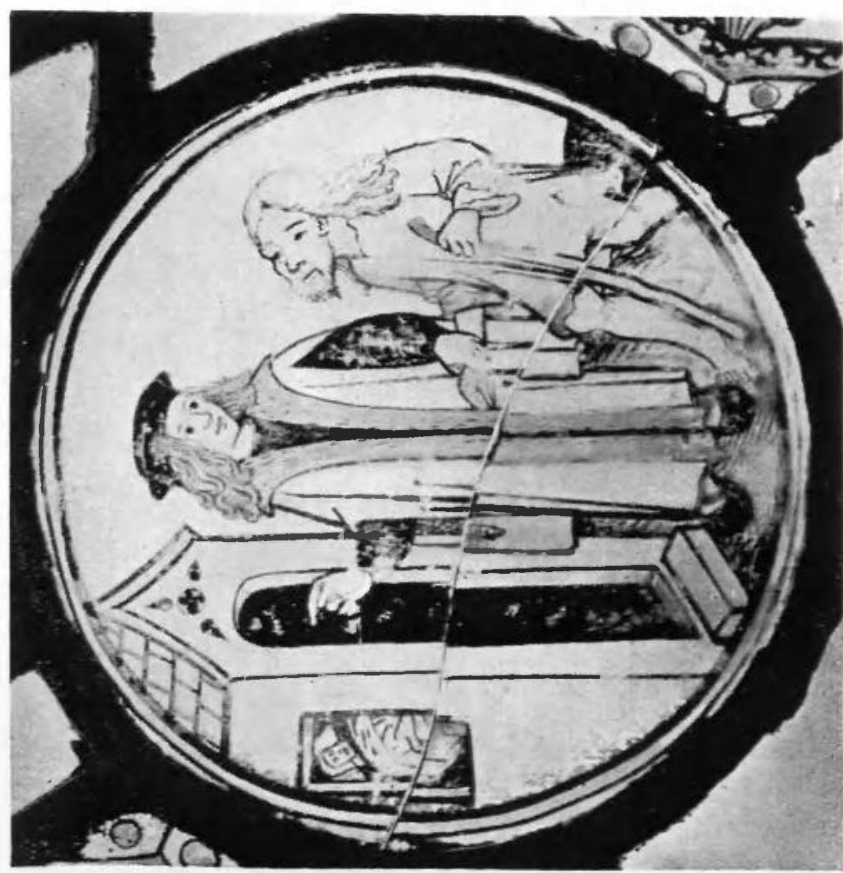

to 
(5) Visiting the sick (plate $\mathrm{x}, 4$ ). It will be noticed that the consolation offered is not spiritual or even medical, but the material one of money. The crutch lying beside his boots tells us that the sick man could only hobble about. The other object may be a foot or leg-rest; and in addition, as Mr. North puts it, "the necessary conveniences of a sick chamber are freely portrayed.'

$V$ isiting the prisoners is missing, but we may assume that it formed one of the series, and has been lost. It is true that only six Works of Mercy are represented in the York window, but this is one of them; and it is inconceivable that one of the Gospel works should be omitted for the sake of retaining Burial, which was added to the original six only to make up the conventional number seven. ${ }^{1}$

We may suppose that the scene followed the York design, where we see three prisoners sitting in the stocks, chained together. The benefactor stands before them with a loaf in one hand, while with the other he is taking some money out of his purse. ${ }^{2}$

(6) Burying the dead (plate $\mathrm{x}, 5$ ). The idea of this as a Work of Mercy was derived from Tobit i, I $7 \cdot{ }^{3}$ We are reminded of the Italian medieval brotherhoods, still in existence, for finding and burying derelict bodies, and assisting at funerals. Our artist has simply taken as his model the ordinary scene of interment, as it was portrayed in hundreds of illuminated liturgical or devotional manuscripts, in connexion with the Office of the Dead. There is nothing which specially suggests a Work of Mercy. The mourners seem to be the relations, perhaps the widow, and a son who holds a candle. I have not been able to find a parallel to the action of the priest touching the corpse with the cross, while he also sprinkles it with holy water. It will be noticed that the body is being buried in its shroud without a coffin, after the ordinary medieval and even later fashion. As is well known, churches had a parish coffin,

1 The fact is six works are represented where there is room for that number and no more, as in the York window and on the twelfth-century ivory cover of the Psalter of Melisenda in the British Museum (A. Maskell, Ivories, p. I 18 ).

2 Reproduced as the frontispiece to $\mathrm{Dr}$.
Nelson's Ancient Painted Glass in England from An Old Tork Cburch.

${ }^{3}$ v. I6, "I gave many alms to my brethren, and gave my bread to the hungry, (17) and my clothes to the naked : and if I saw any of my nation dead, or cast about the walls of Nineve, I buried him.' 
used for bringing the body to the church, and then to the grave; but the corpse was removed from it to be laid in its last resting place. The small cross marked on the shroud is not usual in pictures of funerals, but among the fourteenthcentury wall-paintings in Chalgrove church, Oxfordshire, that of the Last Judgment shows the dead rising out of their graves in shrouds marked with two or more crosses. ${ }^{1}$

THE SINGLE FIGURES.

The Christ (plate $\mathrm{xI}$ ) is not the same thing as the 'Christ of Pity.' The conception seems to be that of the Lord in glory (notice the ample mantle), still retaining the marks of the Passion as symbols of its continual efficacy. In the (more or less contemporary) east window of the Lady chapel in Gloucester cathedral is a similar Christ, against a background of gold rays; but there the right hand is directing a stream of blood from the wounded side on to a kneeling figure. In the late fifteenth-century Creed window at Great Malvern the second article was illustrated by a Christ of similar character, displaying the wounds, and (as here) standing on a red mantle. The intention of the design is well brought out by the accompanying inscription: Ibesus Cbristus deus et bomo.

The four saints are a selection which is quite characteristic of the period. Katharine and Margaret (plate $\mathrm{xII}, \mathrm{I}, 2)$ almost invariably appear in a fifteenth-century series, and Christopher (plate XII, 3) also is very common. George (plate xiII) was (outside Court circles) the least popular of the four; but various efforts were made to spread his cult as the patron of the realm, ${ }^{2}$ and his presence here is, in any case, accounted for by the important local gild of St. George, connected with St. Martin's church. ${ }^{3}$ His armour is of the same pattern as that of the soldiers in

1 Arcbaeologia, xxxviii (1860), pl. xxiii (reproduced in J. C. Wall's Mediaeval $W$ all Paintings, p. 14I).

2 In 1415 Archbishop Chichele ordered that the festival should be kept as a greater double in the province of Canterbury, with abstention from servile work as at the feast of Christmas (Wilkins, Concilia, iii, 376); but, apparently, with little or no effect.

${ }^{3}$ T. North, Cbronicle of the Cburcb of S. Martin in Leicester (London, 1866), p. $236 \mathrm{ff}$. 


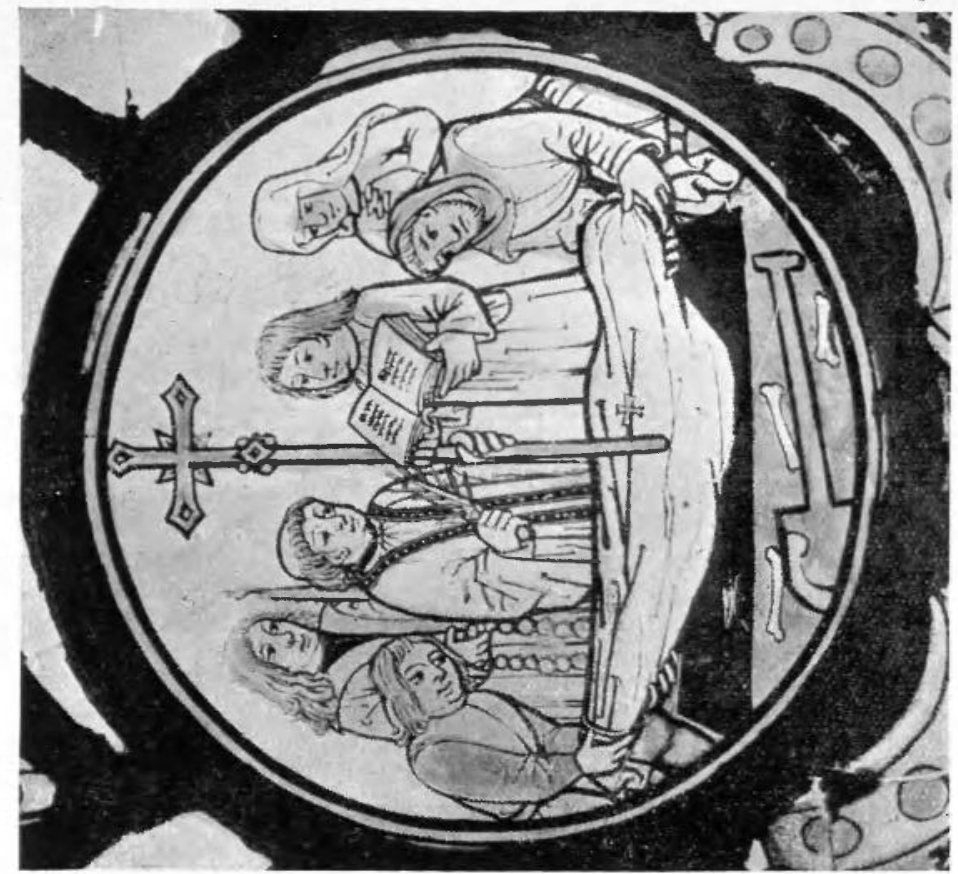

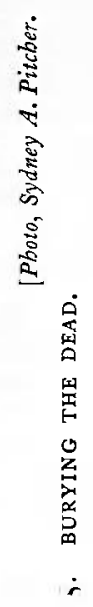

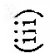

㟧

동

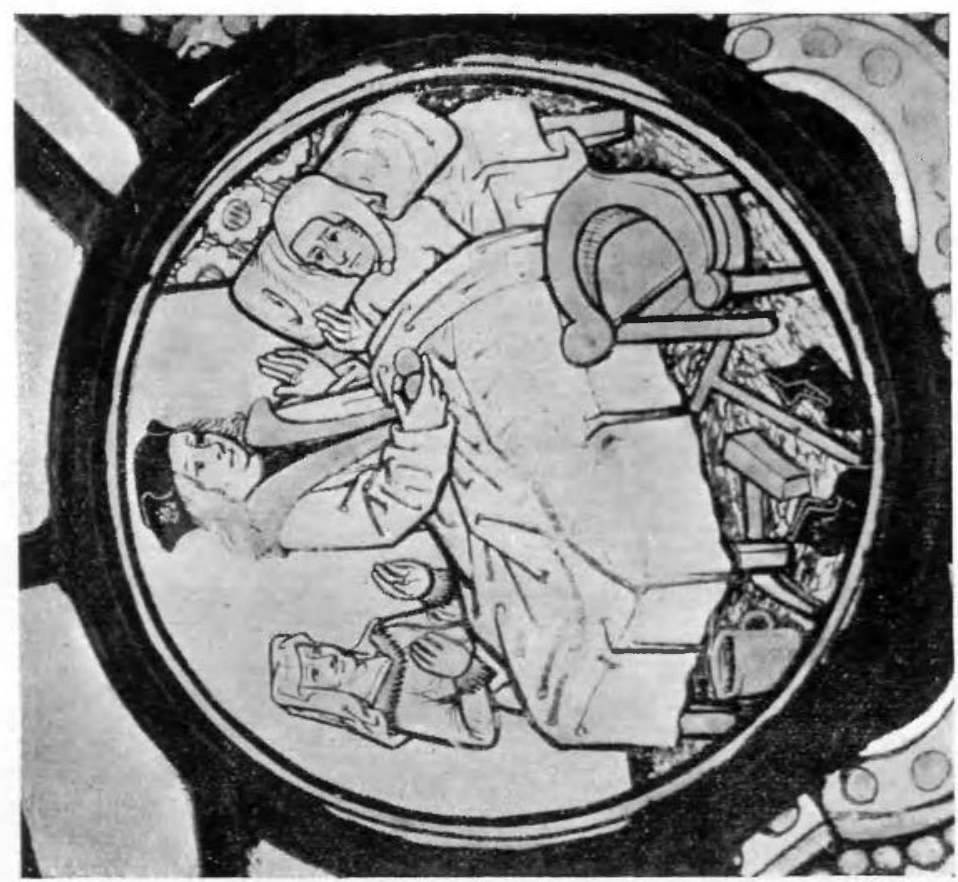




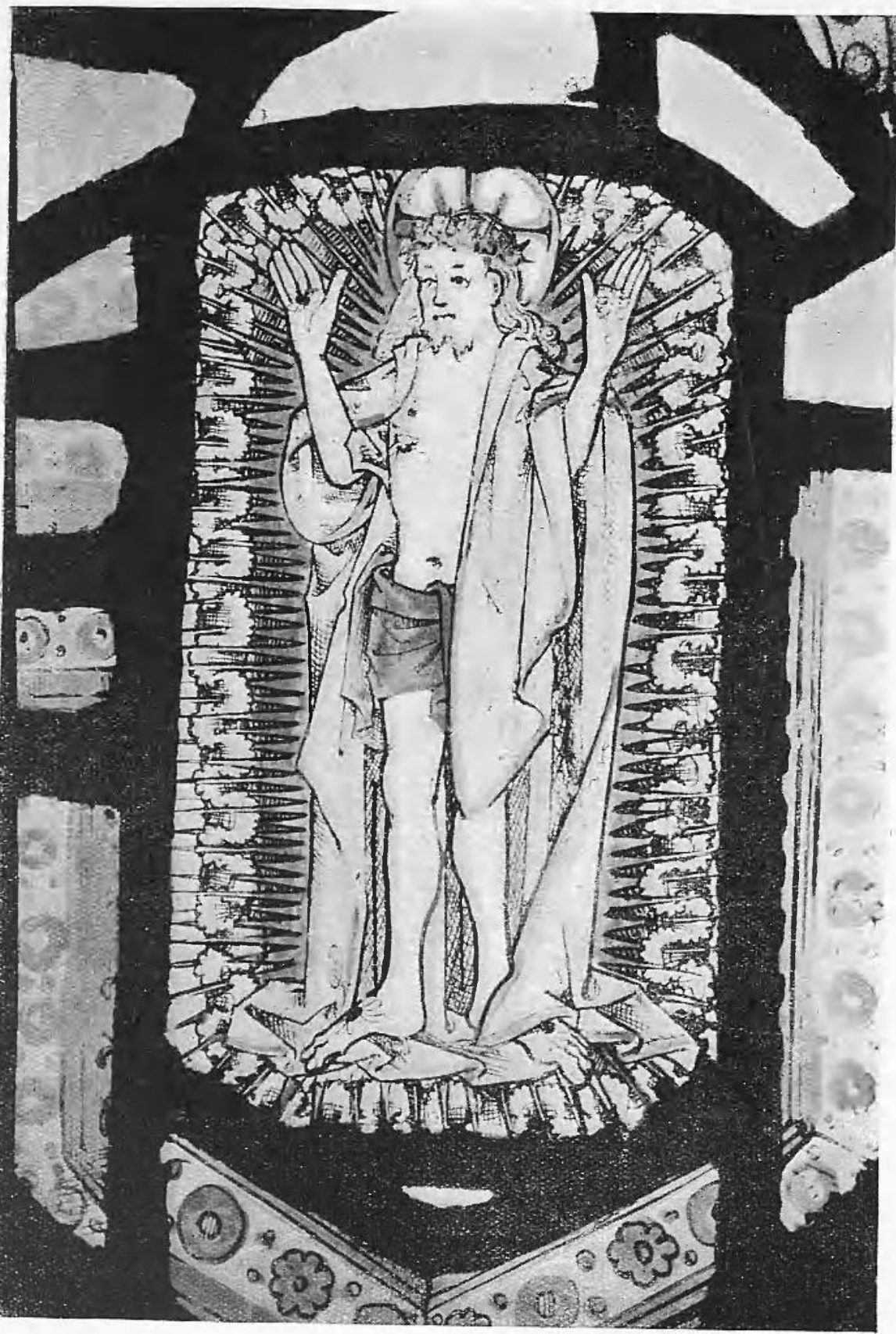

CHRIST IN GLORY.

[Pboto, Sydney A. Pitcher. 
the Resurrection scene (p. 58 above). The virgin saints, as usual, wear the costume of princesses, which we have already described in the case of Mary (p. 56 above).

In addition to these figure-subjects there are three pieces of heraldic glass.

The Town Arms (plate xiv, I, 2) are in the form rather

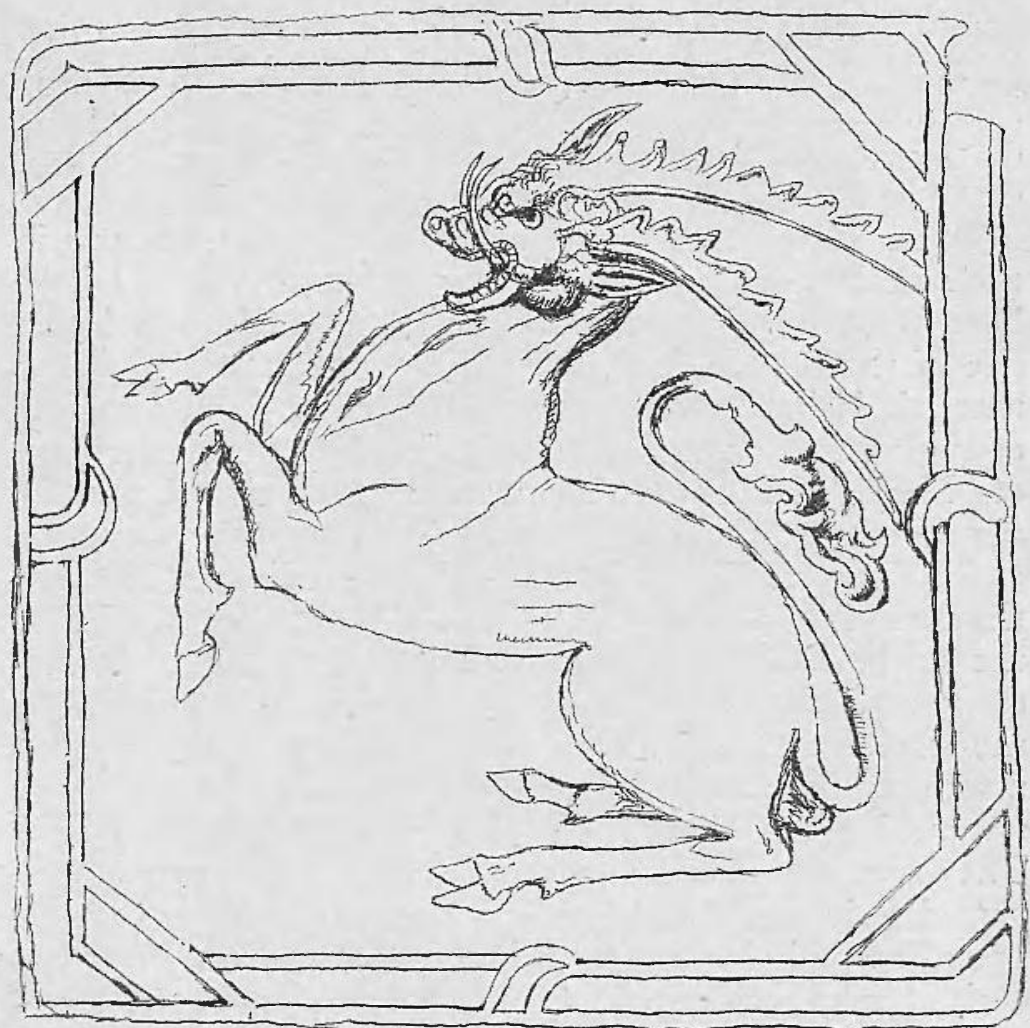

FIG. I. HERALDIC ANTELOPE (from a tracing).

of badges than of armorial bearings. The cinquefoil ermine is enclosed by a twisted wreath, which is common in late fifteenth-century art. It seems to have been framed just like the rest of the series. The so-called crest (apparently framed in the same way) shows something rather different from the wyvern (legless or two-legged) used nowadays. This one has four legs like a dragon, and it is devouring a 
smaller creature of the same kind. I am not aware when the Town crest first appears, but Leicester had a borough seal showing the cinquefoil in a round, as here, since the thirteenth century. ${ }^{1}$

On a quarry in the same light as the cinquefoil is what Mr. North called 'a nondescript animal' (fig. I); but it is clearly the heraldic antelope, used as a supporter by Henry VI, and also by Henry Stafford, duke of Buckingham (beheaded in I525). ${ }^{2}$ Probably there were other heraldic quarries in the window, and they may have illustrated various royal and noble badges. Or the owner of the house may have been a Lancastrian, or have had some connexion with the great house of Stafford.

With regard to the date at which the glass was put in the window, two facts emerge from the survey which we have just made. In the first place, the uniformity in the size of the roundels and in their decorative setting shows that the window was carried out at one time. But costumes, armour, and accessories, in the case of the Joys of Mary, the Seven Sacraments, and the figures of saints, suggest the last quarter of the fifteenth century; and if this were all, we should have little hesitation in fixing the date of the window in that period. On the other hand, the costume of the Works of Mercy suggests, not the last quarter of the fifteenth century, but the first quarter of the sixteenth. And as the latest indications of this sort must date the whole series, we must suppose that the glass was put into the window some time between 1500 and $1525 .^{3}$ The inference would seem to be that, for the two first named series and for the oblong panels, old designs of the preceding period were used, while the Works of Mercy were derived from some more or less contemporary set of compositions. It is not difficult to imagine how this might come about. As we have seen, it was in the last half of the fifteenth century that the output of English painted glass reached its maximum. With the sixteenth century it

\footnotetext{
I M. Bateson, Records of the Borougb of Leicester (London, 1901), ii, pl. i (from deed of 1343, p. 57). The seal was made in $125^{8}$ (i, p. 62).
}

2 In 1492 there was an inn at Leicester called the Antelope. North, Cbronicle, etc. p. 208.

${ }^{3}$ If the antelope badge mentioned above referred to the duke of Buckingham, his execution in 1525 makes it improbable that the glass is later than that year. 


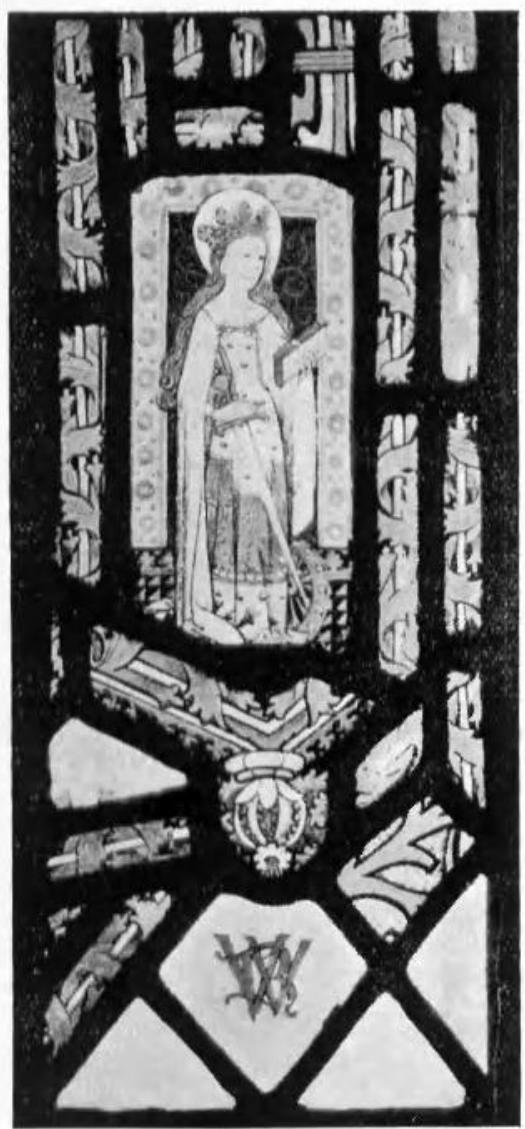

1. ST. KATHARINE.

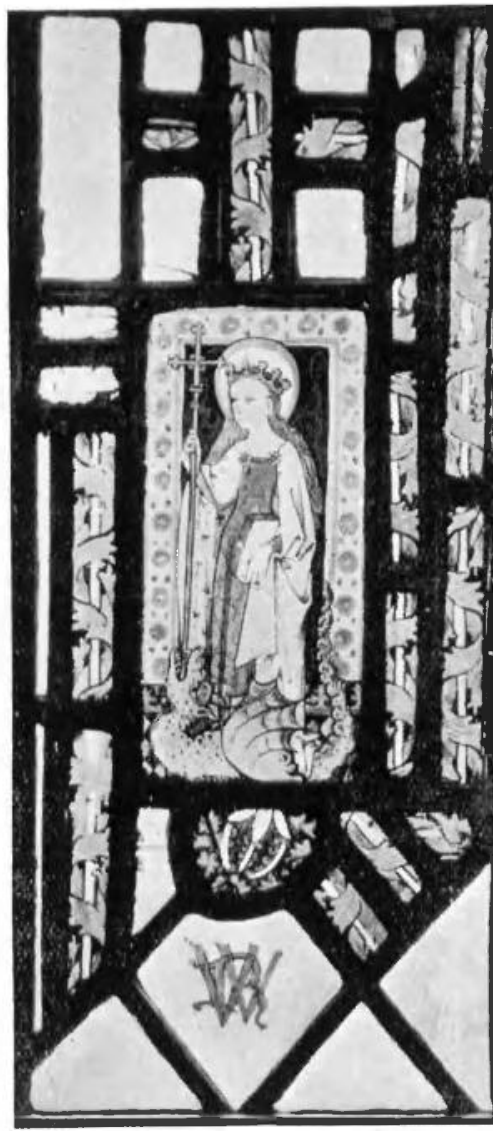

2. ST, MARGARET. 


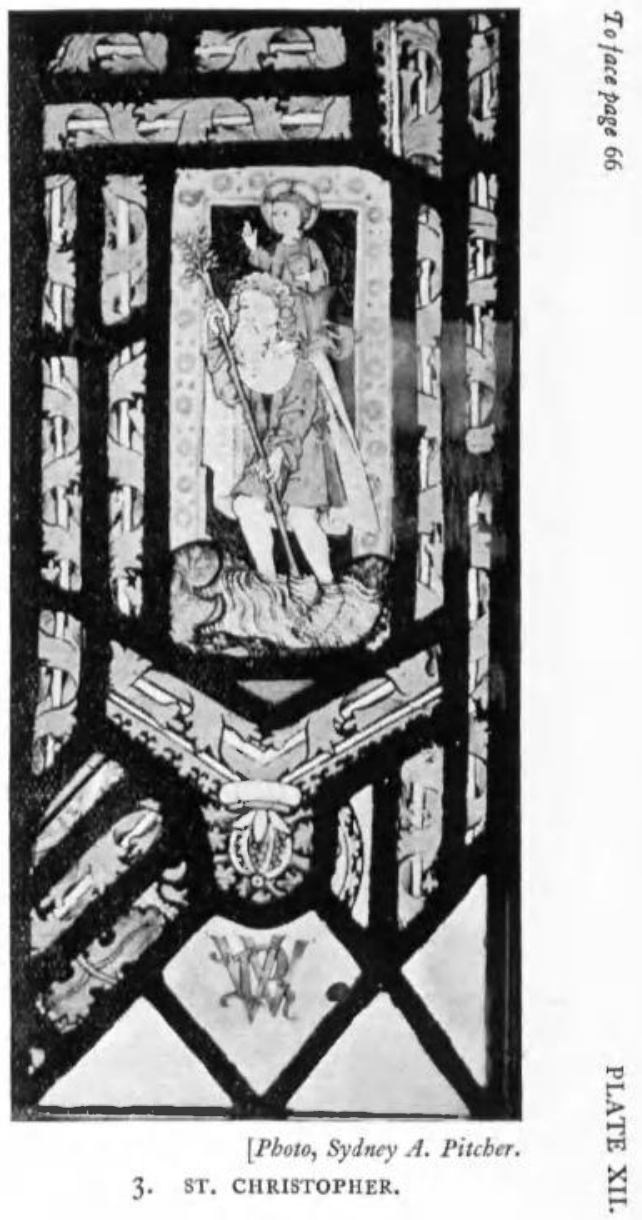




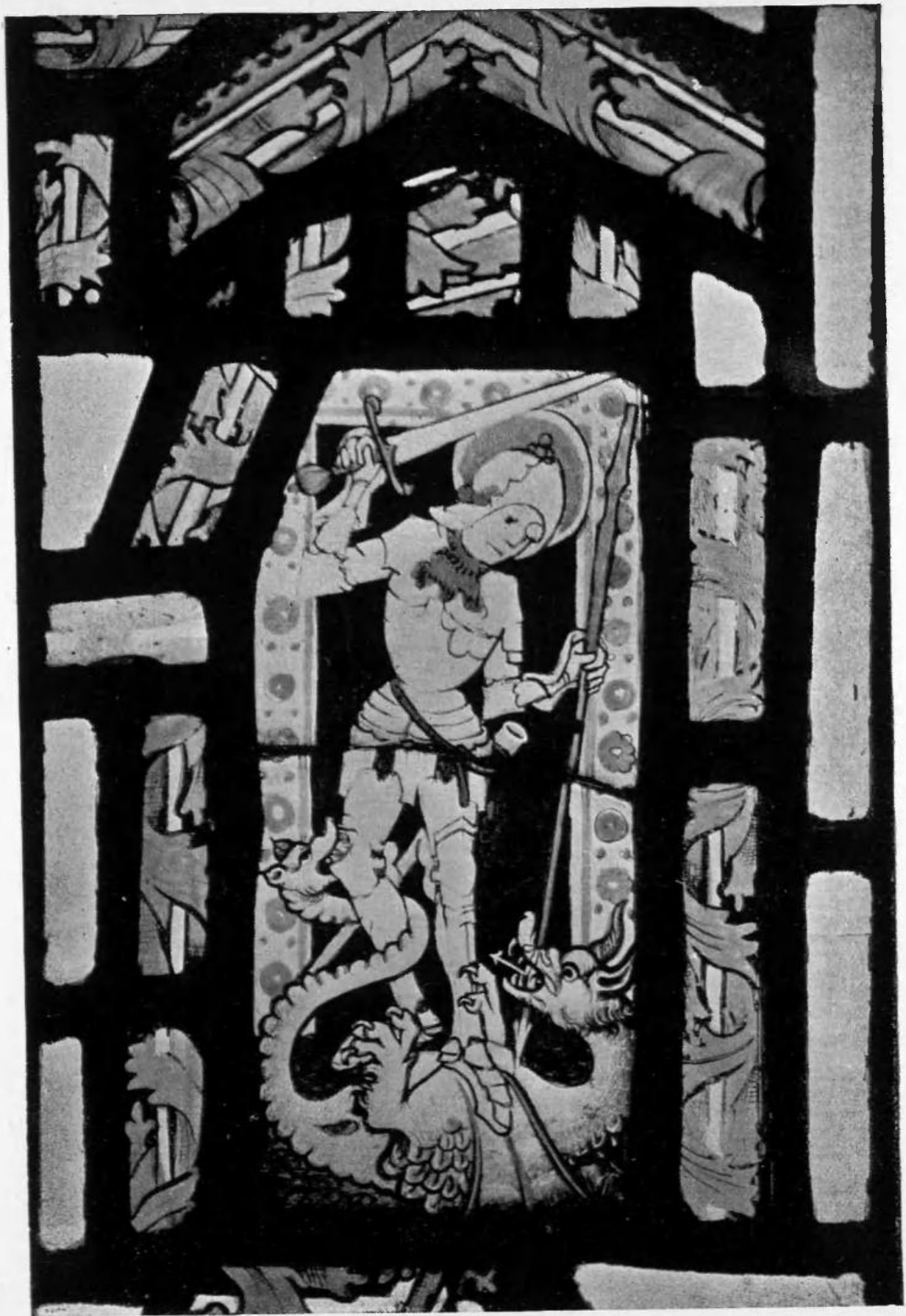


distinctly slackened. And it was in religious subjects, such as those represented in the Seven Sacraments and the Joys of Mary, that the earlier period was specially fertile. In the studios of the glass-painters there must have been an abundance of designs of this nature. The Works of Mercy, however, were not a very common subject, and it may well have been that the Leicester artist had not at hand a set of cartoons for them uniform with the other series. Hence he would have to resort to a set of designs derived from some other and more or less contemporary source.

Finally, the quarries decorated with the interlaced initials $R W$ or $W R$ raise the question, who was the person who put up the glass? Any one who is acquainted with the history and records of Leicester will realise that there is no more likely name than that of Wigston; but until it is proved that the house in Highcross street belonged to some member of that family (and the evidence for that has still to be discovered), any attempt to identify the initials with some member of it must be of the nature of a conjecture. There may, too, have been other Leicester families to which the letters might belong. For instance, at the end of the fifteenth century there was a prominent citizen called William Rawlot or Rowlat, a contemporary of the well-known Roger Wigston (d. 1507), though only of secondary importance compared with him, either in public life, or as an owner of property. But on the whole, the prominence and wealth of the Wigstons make it highly probable that it was a member of this family who owned the house and put up the glass. If the conclusion suggested above as to the date of the glass be correct, it is vain to look for ' $\mathrm{R} \mathrm{W}$ ' among the Wigstons whose careers belonged to the fifteenth century rather than to the sixteenth. We may therefore put aside not only Richard Wigston, who appears in various Leicester records between $I_{4} 64$ and $1_{483}$, but also the more important Roger Wigston (perhaps his brother), in favour of whose claim a good deal might otherwise be said. It is true that he did not die

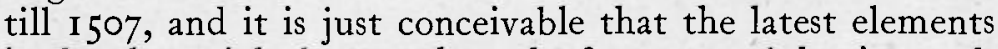
in the glass might be as early as the first years of the sixteenth century. But it is much more reasonable to connect it with some one belonging to the next generation. We do not expect an old man, at the end of his career (as Roger 
Wigston was in 1500 ), to put up a costly piece of decoration in what was, probably, a new house.

Now Roger Wigston had a nephew of the same name, younger brother of the famous William Wigston, the great benefactor of Leicester. $\mathrm{He}$ is, no doubt, the person mentioned in an Inquisition recently published, 1 from which we learn that Walter Langley, holding property in Gloucestershire and elsewhere, died in 1503 leaving three sisters and co-heiresses, the second of whom, Christine, was the wife of Roger Wigston, and aged twenty-five. This looks as if they were young people, starting married life about I 500 ; and this is consistent with the date of Roger's death in 1542. What with his wife's fortune and his own, he must have been a prosperous man. In default of more definite information we may regard him as being the most likely person to have owned, and perhaps built, the house in Highcross street, and to have inserted the painted glass, marked with his initials, in its principal window.

${ }^{1}$ Calendar of Inquisitions p.m. : Henry $V I I$ (1915), ii, pp. 374-5, nos. 589-92. 


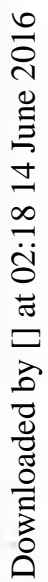

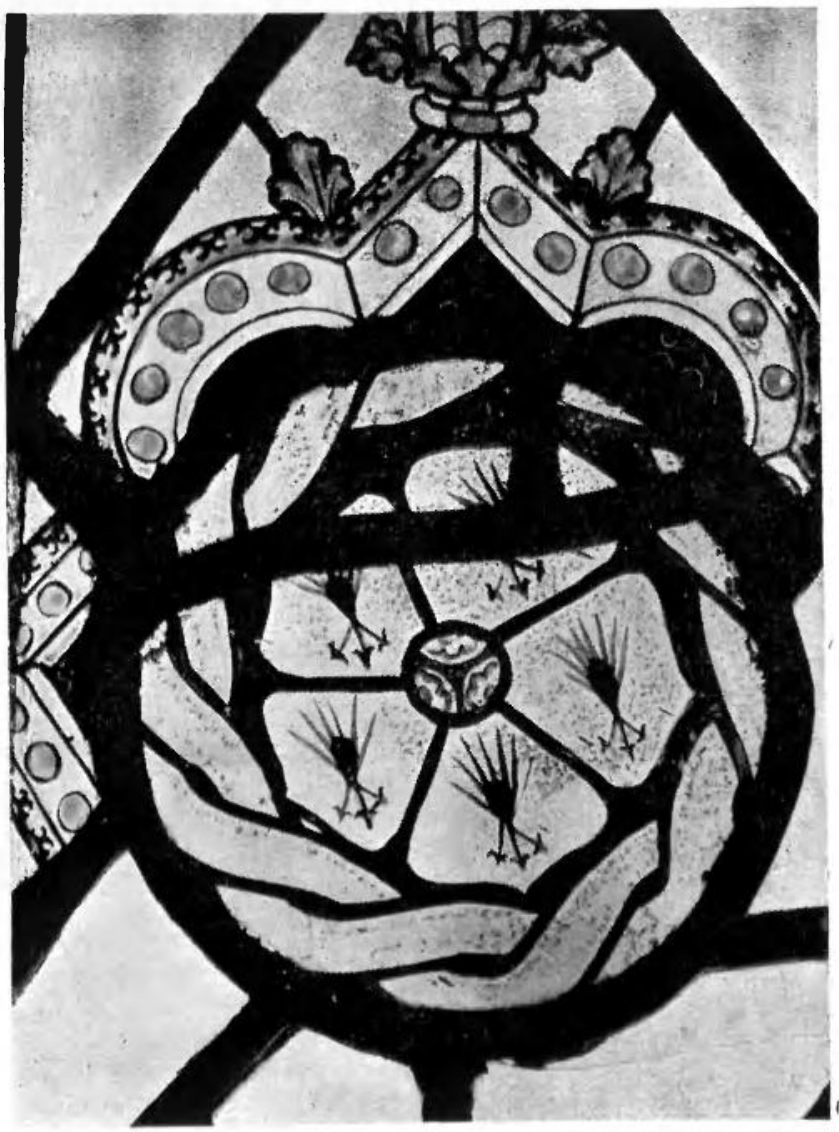

I. ARMS OF TIIE TOWN OF LEICESTER. 


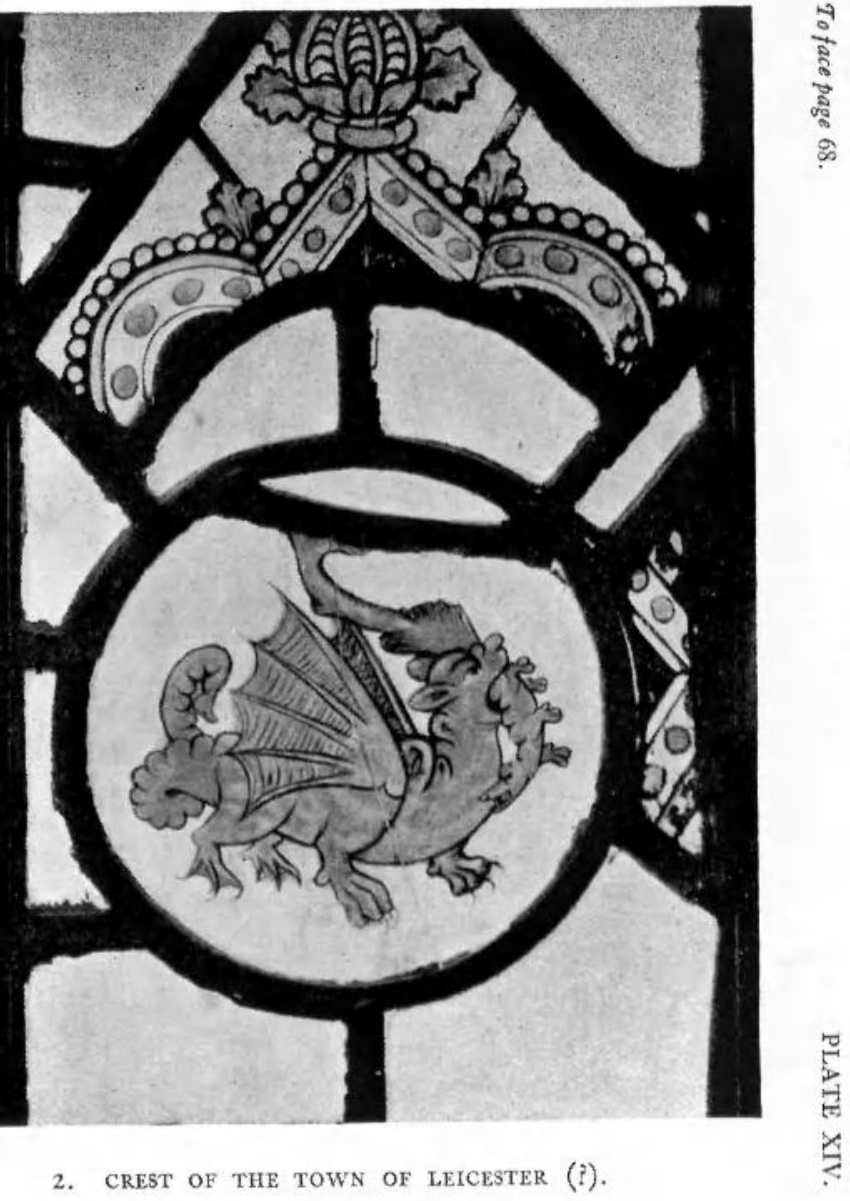

